Article

\title{
Lanthanide(III) Complexes of Cyclen Triacetates and Triamides Bearing Tertiary Amide-Linked Antennae
}

\author{
Salauat R. Kiraev ${ }^{\circledR}$, Emilie Mathieu ${ }^{\circledR}$, Fiona Siemens, Daniel Kovacs, Ellen Demeyere ${ }^{\circledR}$ \\ and K. Eszter Borbas *(1)
}

Department of Chemistry, Ångström Laboratory, Uppsala University, Box 523, 75120 Uppsala, Sweden; salauat.kiraev@kemi.uu.se (S.R.K.); emilie.mathieu@lcc-toulouse.fr (E.M.); fiona.siemens@googlemail.com (F.S.); daniel.kovacs1990@gmail.com (D.K.); Ellen.Demeyere@UGent.be (E.D.)

* Correspondence: eszter.borbas@kemi.uu.se; Tel.: +46-(0)18-471-7340

Academic Editor: Zoltan Kovacs

Received: 22 October 2020; Accepted: 10 November 2020; Published: 12 November 2020

check for updates

\begin{abstract}
The coordination compounds of the trivalent lanthanide ions ( $\operatorname{Ln}(\mathrm{III}))$ have unique photophysical properties. Ln(III) excitation is usually performed through a light-harvesting antenna. To enable Ln(III)-based emitters to reach their full potential, an understanding of how complex structure affects sensitization and quenching processes is necessary. Here, the role of the linker between the antenna and the metal binding fragment was studied. Four macrocyclic ligands carrying coumarin 2 or 4-methoxymethylcarbostyril sensitizing antennae linked to an octadentate macrocyclic ligand binding site were synthesized. Complexation with Ln(III) (Ln = La, Sm, Eu, Gd, Tb, Yb and $\mathrm{Lu}$ ) yielded species with overall $-1,0$, or +2 and +3 -charge. Paramagnetic ${ }^{1} \mathrm{H}$ NMR spectroscopy indicated subtle differences between the coumarin- and carbostyril-carrying Eu(III) and $\mathrm{Yb}$ (III) complexes. Cyclic voltammetry showed that the effect of the linker on the $\mathrm{Eu}(\mathrm{III}) / \mathrm{Eu}(\mathrm{II})$ apparent reduction potential was dependent on the electronic properties of the N-substituent. The Eu(III), $\mathrm{Tb}(\mathrm{III})$ and Sm(III) complexes were all luminescent. Coumarin-sensitized complexes were poorly emissive; photoinduced electron transfer was not a major quenching pathway in these species. These results show that seemingly similar emitters can undergo very different photophysical processes, and highlight the crucial role the linker can play.
\end{abstract}

Keywords: lanthanide; luminescence; DO3A; coumarin; carbostyril; electrochemistry

\section{Introduction}

The luminescence of the coordination compounds of lanthanide ions ( $\operatorname{Ln}(\mathrm{III}))$ has found application in a variety of fields, such as in biological sensing and imaging [1], in fluorescent lamps and lasers [2], and in anti-counterfeiting [3-5]. The direct excitation of $\operatorname{Ln}($ III) is inefficient due to the low absorption coefficients of the Laporte-forbidden $4 \mathrm{f}-4 \mathrm{f}$ transitions [6]. A common method for overcoming the challenge of low $\operatorname{Ln}(\mathrm{III})$ absorptions is to excite the metal ion through a light-harvesting chromophore, a so-called antenna [6,7]. The antenna can transfer the excitation energy to the $\operatorname{Ln}(\mathrm{III})$, thus combining the attractive Ln(III) luminescence properties (sharp, spiked emission peaks, long excited-state lifetimes) with the strong absorption of common organic chromophores. The presence of the antenna offers additional benefits. It can carry reactive groups for attachment to biomolecules [8], or labels (e.g., F-19) [9] for creating multimodal imaging agents. The antenna can also provide a way to render the $\operatorname{Ln}(\mathrm{III})$ complex analyte-responsive [10-14].

Given the importance of the energy transfer for $\operatorname{Ln}(\mathrm{III})$ sensitization, it is not surprising to see the amount of research dedicated to the optimization of the antenna photophysical properties. Helpful guidelines are available for the matching of Ln(III) with the antenna, which discuss the antenna 
single-triplet gap, and the energy gap between the antenna triplet and the Ln(III) receiving levels [15]. Both the antenna and the lanthanide excited states are susceptible to quenching, which needs to be minimized if highly emissive complexes are to be obtained. Ln(III) have 8-9 coordination sites, most of which need to be occupied by a multidentate ligand for the complex to be kinetically and thermodynamically stable [16]. Furthermore, $X-H(X=O, N, C)$ oscillators quench Ln(III) excited states $[17,18]$, and should thus be eliminated if possible. The complexes shown in Figure 1 have only one inner-sphere water molecule.

Recently, we reported that $\operatorname{Ln}(\mathrm{III})$ complexes sensitized by carbostyril antennae that are attached to the metal binding site via tertiary amide linkers are substantially more luminescent than the analogous secondary amide-linked ones (Figure 1a) [19]. While the amide linker certainly influences the antenna excited states, the effect is rather subtle. Furthermore, an X-ray crystal structure of a precursor of the tertiary amide-linked complexes indicated that the orientation of the antenna in the two types of emitters may be different, which could have a substantial effect on the energy transfer efficiency.

a)

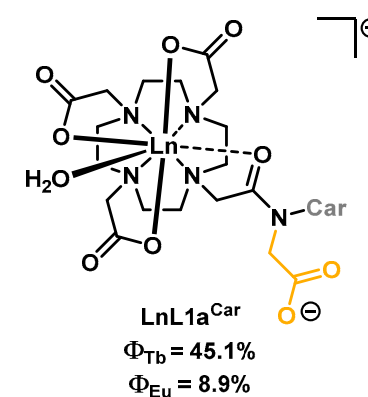

b) Negative-charged amide linker Neutral amide linker ('BuOAc-)

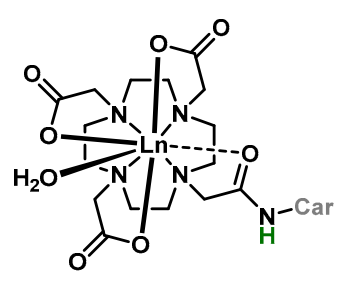

LnL1b ${ }^{\text {Car }}$ $\Phi_{\text {Tb }}=27.6 \%$ $\Phi_{\mathrm{Eu}}=5.1 \%$

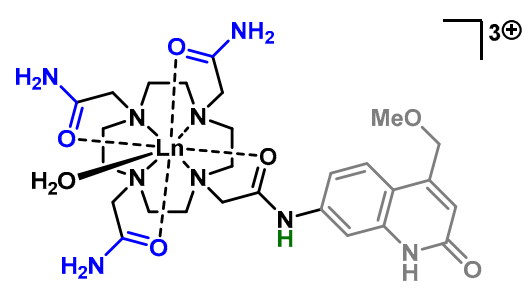

LnL2b ${ }^{\text {Car }}$

$\Phi_{\mathrm{Tb}}=\mathbf{2 6 \%}$ $\Phi_{\mathrm{Eu}}=1 \%$

Neutral amide linker (Et-)

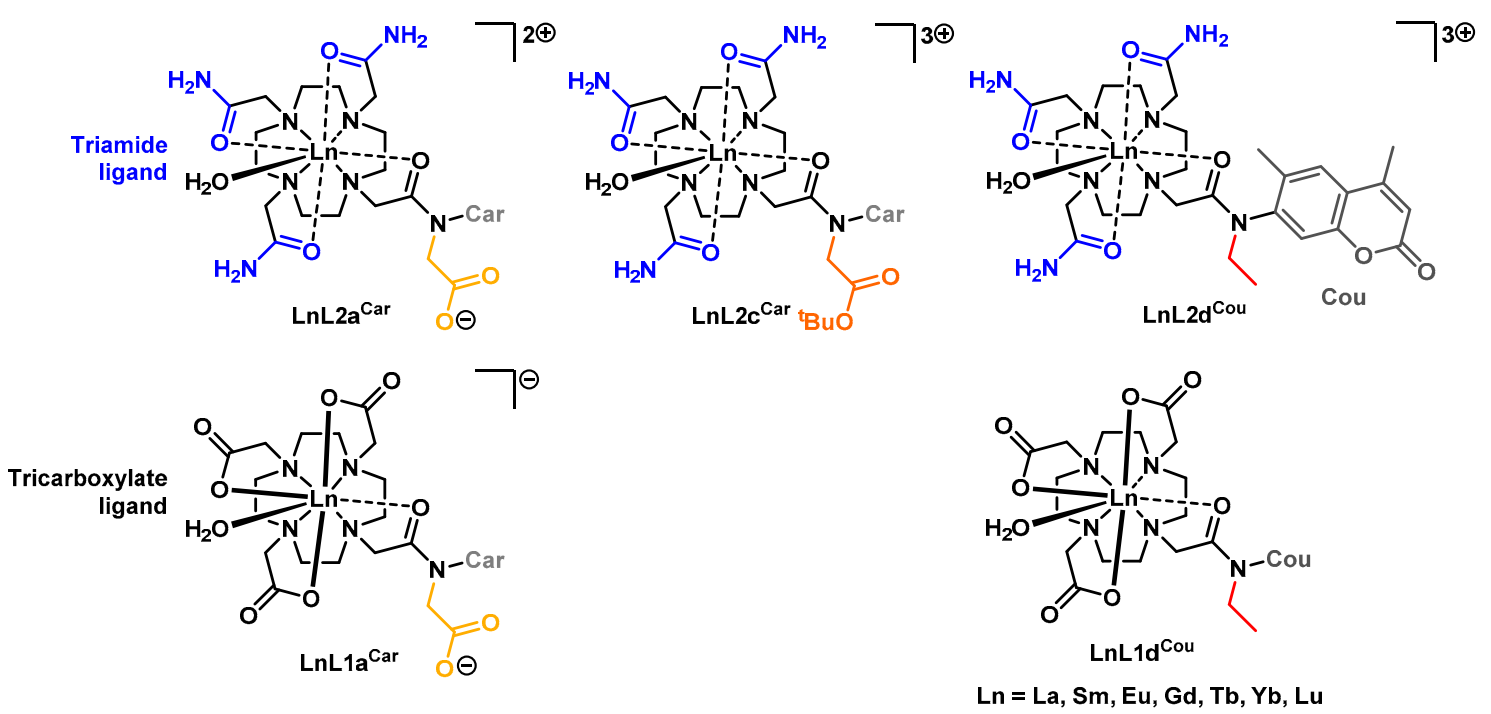

Figure 1. (a) Comparison of the $\mathrm{Eu}(\mathrm{III})$ and $\mathrm{Tb}(\mathrm{III})$ luminescence quantum yields of secondary and tertiary amide-linked carbostyril-sensitized Ln(III) complexes. (b) Complexes studied here.

Possible structural effects that explain the differences observed between the photophysical properties of secondary and tertiary amide-linked complexes are investigated in this work. We studied the effect of charge on the amide linker substituent, and whether the effect is carried over to complexes carrying a coumarin antenna or a ligand binding site wherein the three carboxylate donors were replaced by three amides (Figure $1 b)$. 


\section{Results}

\subsection{Synthesis}

The syntheses of $\mathbf{L n L 1 a}^{\mathrm{Car}}$ and $\mathrm{LnL1d}^{\mathrm{Cou}}$ have been reported previously, except their La, Sm, Yb

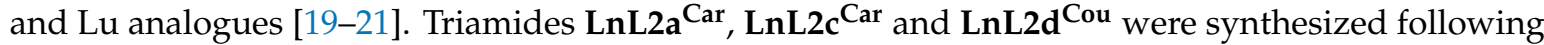
analogous procedures, these are summarized in Scheme 1. Detailed synthetic protocols and complete characterization of all new compounds are given in the Materials and methods. Syntheses started from known monoalkylated cyclens 1 [22] or 6 [20]. Trialkylation with bromoacetamide was carried out in the presence of diisopropyl ethylamine (DIPEA) or $\mathrm{K}_{2} \mathrm{CO}_{3}$ to yield $\mathbf{L} 2 \mathbf{c}^{\mathrm{Car}}$ or $\mathbf{L} 2 \mathrm{~d}^{\mathrm{Cou}}$, respectively. Heating the latter at $55{ }^{\circ} \mathrm{C}$ in an aqueous-ethanolic mixture with a slight excess of $\mathrm{LnCl}_{3}$ afforded LnL2d Cou $(\mathrm{Ln}=\mathrm{La}, \mathrm{Sm}, \mathrm{Eu}, \mathrm{Gd}, \mathrm{Tb}, \mathrm{Yb}$ and $\mathrm{Lu})$ in high yield. Stirring $\mathrm{L2c}^{\mathrm{Car}}$ in a 1:1 mixture of $\mathrm{CH}_{2} \mathrm{Cl}_{2}$ and trifluoroacetic acid (TFA) overnight cleaved the tert-butyl ester in the tertiary amide side

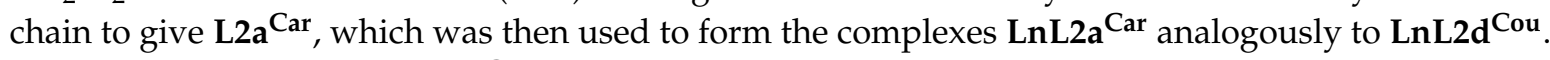
The reaction mixtures of $\mathbf{L n L 2} \mathbf{a}^{\text {Car }}$ had to be purified via semipreparative HPLC to afford analytically pure samples, as the complexes partially decomposed during synthesis. We attempted to synthesize the tert-butyl-protected $\mathbf{L n L 2 c}{ }^{C a r}$ the same way as the other $\mathbf{L n L 2}$ triamide species. The ${ }^{\text {t}} \mathrm{Bu}$ ester in the Ln(III) complexes was labile, and hydrolyzed quantitatively to LnL2aCar. This was confirmed by LC-MS analysis of their reaction mixtures stirred overnight which showed the presence of both LnL2aCar and LnL2c Car species in a 1:2 ratio (Figures S1-S3). The ${ }^{1} \mathrm{H}$ spectra of LaL2cCar and LuL2cCar confirmed the presence of both hydrolyzed and ${ }^{\mathrm{t}} \mathrm{Bu}$ ester-protected species in 1:0.45 and 1:0.25 ratios, respectively (Figures S4 and S5).

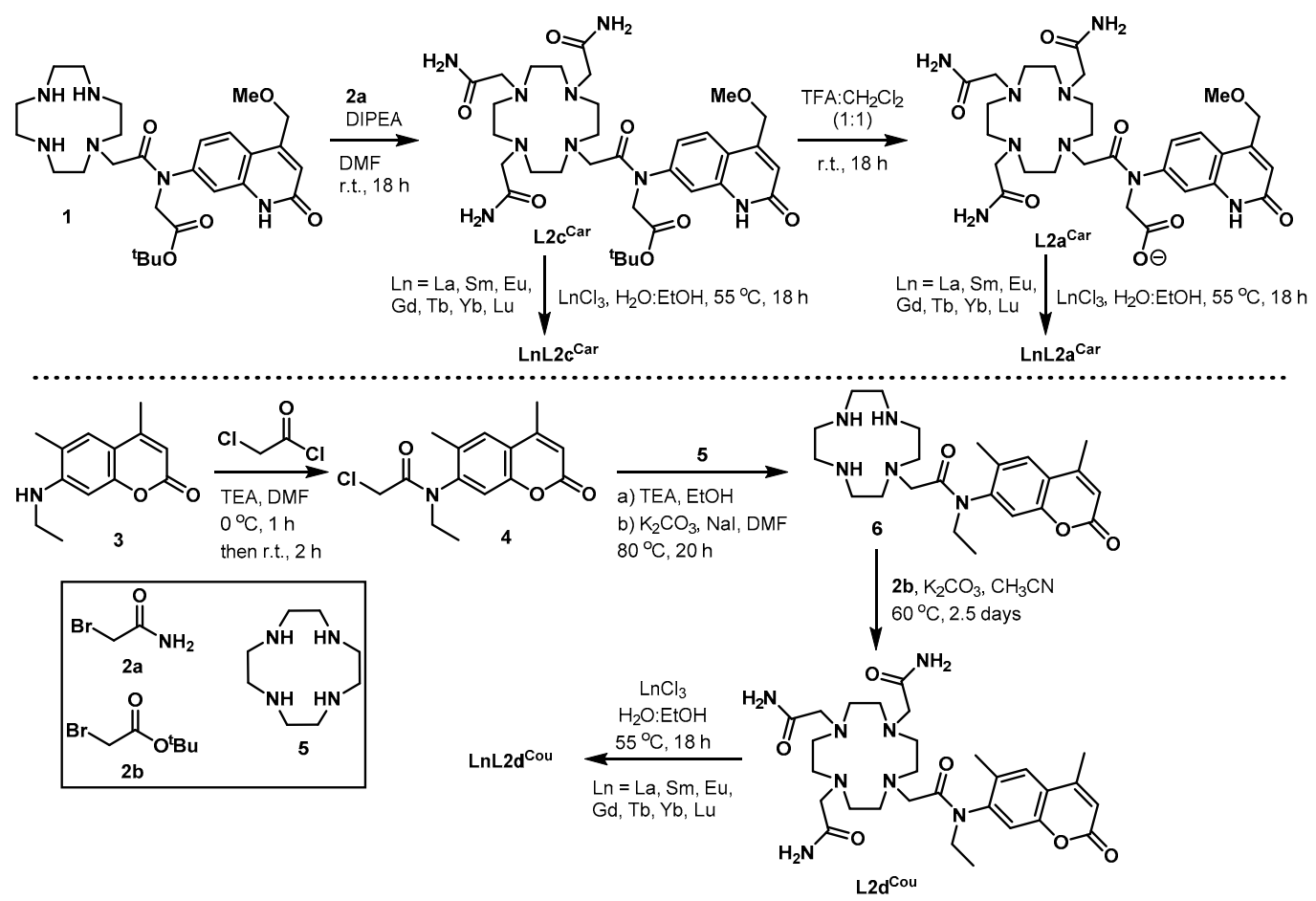

Scheme 1. Synthesis of new ligands and complexes.

\subsection{Paramagnetic ${ }^{1} \mathrm{H} N \mathrm{~N} R$ Spectroscopy}

Cyclen-based DO3A-type Ln complexes interconvert between several structures in solution [23]. This dynamic process was studied by paramagnetic ${ }^{1} \mathrm{H}$ NMR spectroscopy of the Eu(III) and Yb(III) chelates (Figures 2 and 3). The spectra of the diamagnetic La(III) and Lu(III) complexes were similar to those of the ligands (Figures S6-S13). Eu(III) and $\mathrm{Yb}$ (III) paramagnetic centers caused broadening and relocation of the signals due to the exchange between square antiprism (SAP) and twisted SAP 
(TSAP) isomers (Figures S14-S25). The resonances belonging to SAP and TSAP isomers can be distinguished from their different signals of axial cyclen ring protons [24]. Well-defined signals could be obtained upon cooling down the solutions of the Eu(III) complexes [25]. Tricarboxylate complexes EuL1a $^{\text {Car }}$ and EuL1d ${ }^{\text {Cou }}$ were present as mixtures of TSAP (12.6-12.8 ppm and 11.9-13.5 ppm) and SAP (32.2-36.3 ppm and 32.5-36.3 ppm) conformers in $\mathrm{D}_{2} \mathrm{O}$ at $10{ }^{\circ} \mathrm{C}$ (Figure 2). The ratios of the signals attributed to the SAP and TSAP species were 1:0.22 and 1:0.34 for EuL1aCar ${ }^{\text {and EuL1d }}{ }^{\text {Cou }}$, respectively (Figures S14 and S18). The spectra of triamide EuL2a Car , EuL2c Car and EuL2d ${ }^{\text {Cou }}$ complexes in CD $_{3} \mathrm{OD}$ at $0^{\circ} \mathrm{C}$ contained only signals from the SAP isomer (30.6-33.1, 29.9-32.8 and 29.9-33.2 ppm, respectively), as did all the $\mathrm{Yb}(\mathrm{III})$ complexes at r.t. (YbL1: 112.5-133.5 ppm ( $\left.\mathrm{D}_{2} \mathrm{O}\right)$, YbL2: 95.0-113.3 ppm ( $\mathrm{D}_{2} \mathrm{O}$ and $\left.\mathrm{CD}_{3} \mathrm{OD}\right)$, Figure 3).

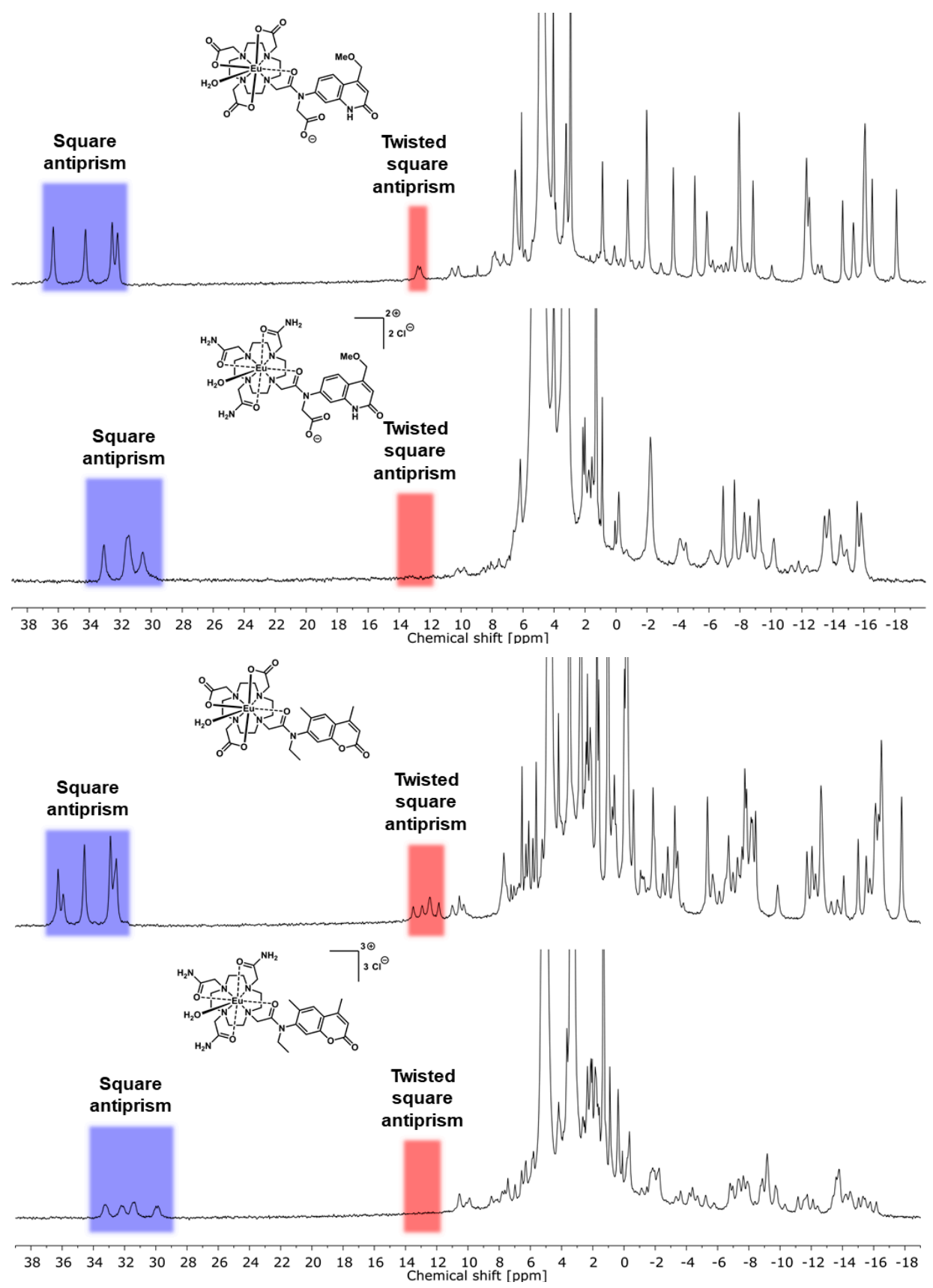

Figure 2. Stacked ${ }^{1} \mathrm{H}$ NMR spectra $(400 \mathrm{MHz})$ of Eu complexes measured in $\mathrm{D}_{2} \mathrm{O}$ (EuL1aCar and EuL1d $\left.{ }^{\mathrm{Cou}}\right)$ at $10{ }^{\circ} \mathrm{C}$ and $\mathrm{CD}_{3} \mathrm{OD}\left(\right.$ EuL2a ${ }^{\mathrm{Car}}$ and EuL2d $\left.{ }^{\mathrm{Cou}}\right)$ at $0{ }^{\circ} \mathrm{C}$ with the regions corresponding to TSAP and SAP cyclen ring protons in red and blue, respectively. 

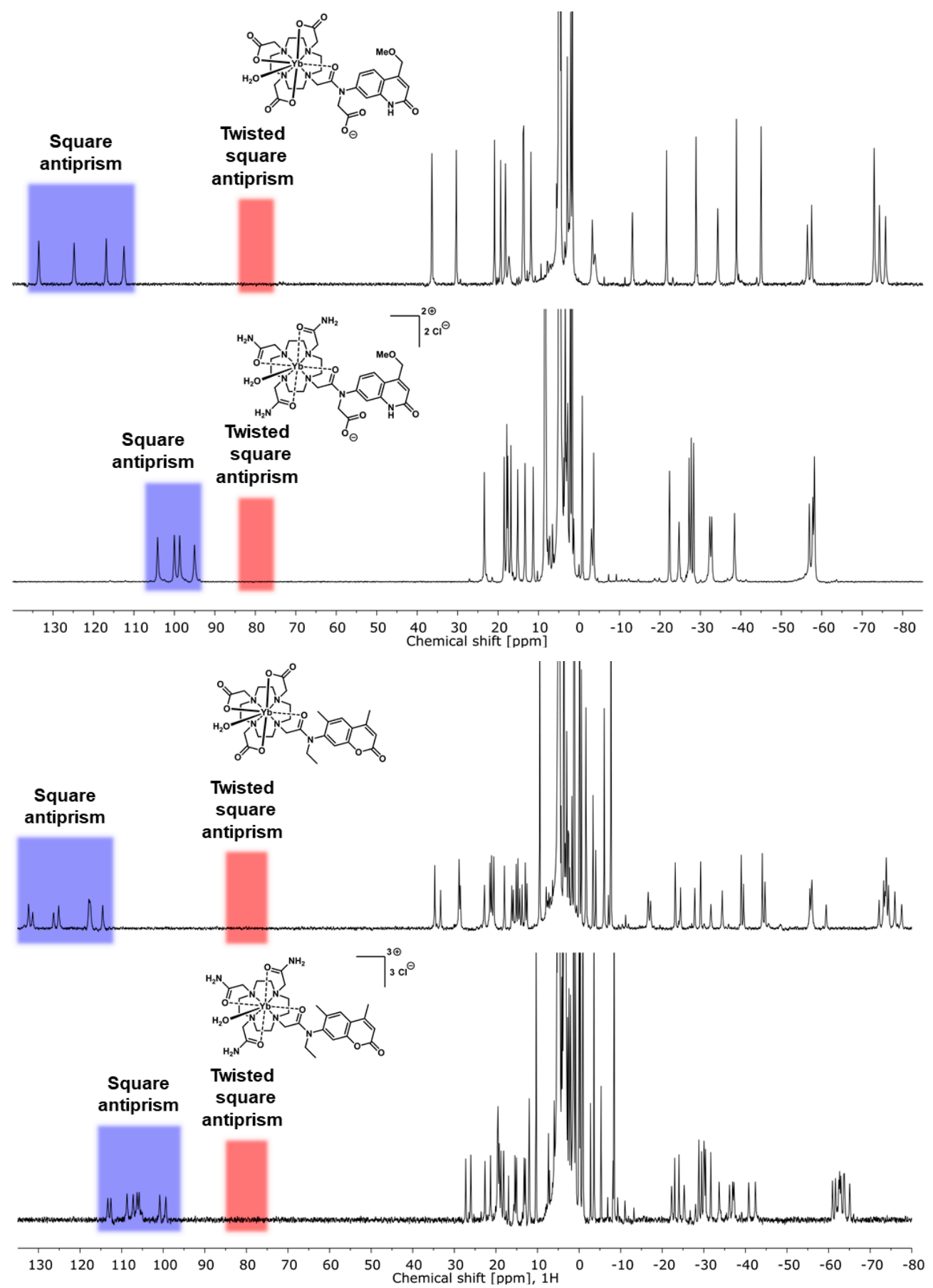

Figure 3. Stacked ${ }^{1} \mathrm{H}$ NMR spectra $(400 \mathrm{MHz})$ of $\mathrm{Yb}$ complexes measured at r.t. in $\mathrm{D}_{2} \mathrm{O}\left(\mathrm{YbL1a}^{\text {Car }}\right.$, YbL1d ${ }^{\mathrm{Cou}}$ and $\left.\mathbf{Y b L 2} \mathbf{a}^{\mathrm{Car}}\right)$ and $\mathrm{CD}_{3} \mathrm{OD}\left(\mathbf{Y b L 2 d}^{\mathrm{Cou}}\right)$ with the regions corresponding to TSAP and SAP cyclen ring protons in red and blue, respectively.

The most downfield signals are assigned to the pseudo-axial cyclen ring protons in the SAP conformers $[26,27]$. In the unsymmetrical complexes discussed here, up to four signals are expected. This is the case in the carbostyril complexes, where the ${ }^{1} \mathrm{H}$ NMR spectra of both the Eu and $\mathrm{Yb}$ species have four distinct peaks in the 32-36/30-33 ppm and 112-133/95-113 ppm (tricarboxylate/triamide) regions, respectively. However, the spectra of the coumarin-appended complexes present more than four well-resolved signals in most cases, indicating the presence of more than one complex with SAP conformation (Figures 2 and 3, bottom). A possible reason for this observation may be restricted rotation of the antenna due to steric clash between the 6-Me and amide $\mathrm{C}=\mathrm{O}$ groups. 


\subsection{Cyclic Voltammetry}

One of the processes that can quench the excited antenna is photoinduced electron transfer (PeT) to the $\mathrm{Ln}(\mathrm{III})$. PeT is often thermodynamically feasible for $\mathrm{Eu}$ and $\mathrm{Yb}$, but not for $\mathrm{Gd}$ and $\mathrm{Tb}$, as the latter two have very negative reduction potentials $\left(\mathrm{E}\left(\mathrm{Gd}^{\mathrm{III}} / \mathrm{Gd}^{\mathrm{II}}\right)=-3.9 \mathrm{~V}\right.$ and $\mathrm{E}\left(\mathrm{Tb}^{\mathrm{III}} / \mathrm{Tb}^{\mathrm{II}}\right)=-3.7$ $\mathrm{V}$ vs NHE, respectively [28]). The driving force for PeT is larger for $\mathrm{Ln}(\mathrm{III})$ with more positive reduction potentials [29]. There is ample evidence that the reduction potential of the $\mathrm{Ln}(\mathrm{III})$ depends on the ligand [30-35]. The replacement of neutral amide donors with -1 charged carboxylates in DO3A-type ligands has been found to shift the Eu(III) reduction potential to more negative values by $\sim 95 \mathrm{mV} /$ donor [36]. We expected that more subtle tuning may be achieved by the manipulation of the antenna linker. This hypothesis was investigated by cyclic voltammetry, the results are summarized in Table 1.

Similarly to what was observed previously [36], the replacement of tricarboxylate by triamide ligand in coumarin complexes increases the $\mathrm{Eu}(\mathrm{III}) / \mathrm{Eu}(\mathrm{II})$ reduction potential from $-854 \mathrm{mV}$ vs NHE in EuL1d ${ }^{\mathrm{Cou}}$ to $-565 \mathrm{mV}$ vs NHE in EuL2d ${ }^{\mathrm{Cou}}$, which corresponds to $~ 96 \mathrm{mV} /$ donor (Table 1).

The introduction of a negatively-charged amide linker in EuL1a ${ }^{\mathrm{Car}}$ and EuL2a ${ }^{\mathrm{Car}}$ leads to a 109 $\mathrm{mV}$ and $58 \mathrm{mV}$ decrease in the apparent $\mathrm{Eu}(\mathrm{III}) / \mathrm{Eu}$ (II) reduction potentials, respectively, compared to EuL1b ${ }^{\mathrm{Car}}$ and EuL2b ${ }^{\mathrm{Car}}$ with secondary amide-linked antennae (Figure 4, Table S3). The shift is most likely due to the additional negative charge on the linker, as the reduction potentials of

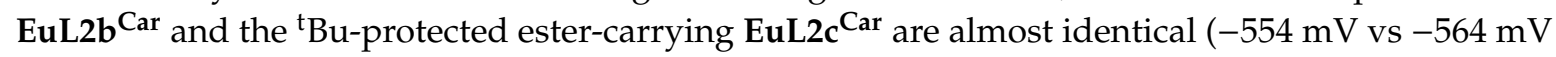
vs NHE, respectively). The apparent reduction potential of EuL1d ${ }^{\mathrm{Cou}}$ is only $15 \mathrm{mV}$ lower than the secondary amide-linked EuL1b ${ }^{C a r}$. Hence, the influence of the neutral amide linker ( ${ }^{\mathrm{t}} \mathrm{Bu}$-protected methylcarboxylate or Et) on the reduction potential is small (Figure S26), whereas the negatively charged arm leads to a better stabilization of Eu(III). It is possible that the replacement of the carbostyril heterocycle with a coumarin 2 also has a slight influence. Either way, the effects are small (Figure S27) and are in the measurement error range $(\sim 10 \mathrm{mV}$ at a scan rate $100 \mathrm{mV} / \mathrm{s}$ [36]).

From the above data we can conclude that the electronic impact of the amide linker in EuL1aCar can be ascribed to its negative charge, which contributes to the stabilization of the +3 oxidation state.

Table 1. Cyclic voltammetry of Eu(III) complexes (positively charged complexes are with Cl-counterions) ${ }^{[\mathrm{a}]}$.

\begin{tabular}{ccccc}
\hline Compound & $\boldsymbol{E}_{\mathbf{1 / 2}}{ }^{[\mathbf{b}]}$ & $\boldsymbol{E}_{\mathbf{p a}}{ }^{[\mathbf{b}]}$ & $\boldsymbol{E}_{\mathbf{p c}}{ }^{[\mathbf{b}]}$ & $\Delta \boldsymbol{E}^{[\mathbf{b}]}$ \\
\hline $\mathrm{EuCl}_{3}$ & -384 & -337 & -431 & 94 \\
\hline EuL1aCar & $-948\left(-839^{[\mathrm{c}]}\right)$ & -766 & -1131 & 365 \\
EuL2aCar $_{\text {EuL2cCar }}$ & $-612\left(-554^{[\mathrm{d}]}\right)$ & -437 & -787 & 350 \\
EuL1d $^{\text {Cou }}$ & -564 & -437 & -691 & 254 \\
EuL2d $^{\text {Cou }}$ & -854 & -744 & -965 & 221 \\
\hline
\end{tabular}

[a] $E_{1 / 2}$ is a half-wave potential, $E_{\mathrm{pa}}\left(\mathrm{E}_{\mathrm{pc}}\right)$ is anodic (cathodic) peak potential, $\Delta E$ is peak separation. ${ }^{[\mathrm{b}]}$ Values are in $\mathrm{mV}$ vs. NHE. Measured in $\mathrm{H}_{2} \mathrm{O}(\mathrm{LiCl} 0.1 \mathrm{M}, \mathrm{pH} \sim 6.5)$ with a sample concentration of $1 \mathrm{mM}$ at a glassy C electrode using a SCE as reference electrode and a Pt wire counter electrode with a scan rate of $100 \mathrm{mV} / \mathrm{s}$. [c] $E_{1 / 2}$ of the corresponding secondary amide complex EuL1b ${ }^{\mathrm{Car}}$, from [36]. ${ }^{[\mathrm{d}]} E_{1 / 2}$ of the corresponding secondary amide complex EuL2b ${ }^{\text {Car }}$, from [36]. 


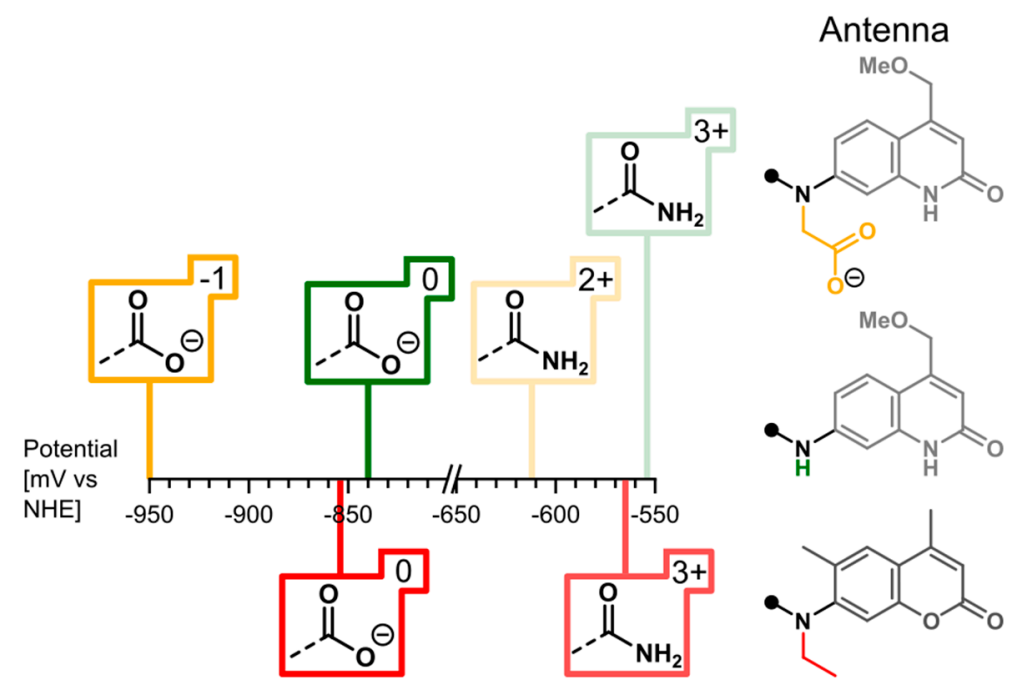

Figure 4. Coordination environment vs apparent $\mathrm{Eu}(\mathrm{III}) / \mathrm{Eu}(\mathrm{II})$ reduction potential of EuL complexes.

EuL1-2a ${ }^{\text {Car }}$ are in dark yellow, EuL1-2b ${ }^{\text {Car }}$ are in dark green and EuL1-2d ${ }^{\text {Cou }}$ are in red.

\subsection{Photophysical Characterization}

The UV-Vis absorption and emission properties of the complexes were studied in $10 \mathrm{mM}$ PIPES buffer in $\mathrm{H}_{2} \mathrm{O}$ or $\mathrm{D}_{2} \mathrm{O}$ ( $\mathrm{pH}$ or $\mathrm{pD}$ 6.5) at r.t. at nominally $10 \mu \mathrm{M}$ concentrations. The new carbostyril-carrying complexes had UV-Vis absorption spectra that resembled those of the previously reported LnL1aCar. Only small variations were seen between complexes of the same ligand with different Ln(III) ions (Figure 5, left), and the complexes had local absorption maxima at $\lambda_{\mathrm{abs}}=328 \mathrm{~nm}$. Replacing the tricarboxylate metal-binding framework with a triamide one essentially did not impact the complex absorptions (Figure S42). Coumarin-appended LnL1d ${ }^{\mathrm{Cou}}$ and LnL2d ${ }^{\mathrm{Cou}}$ similarly had superimposable absorption spectra (Figure 5, right), with $\lambda_{\mathrm{abs}}=319 \mathrm{~nm}$ (Figure S43).

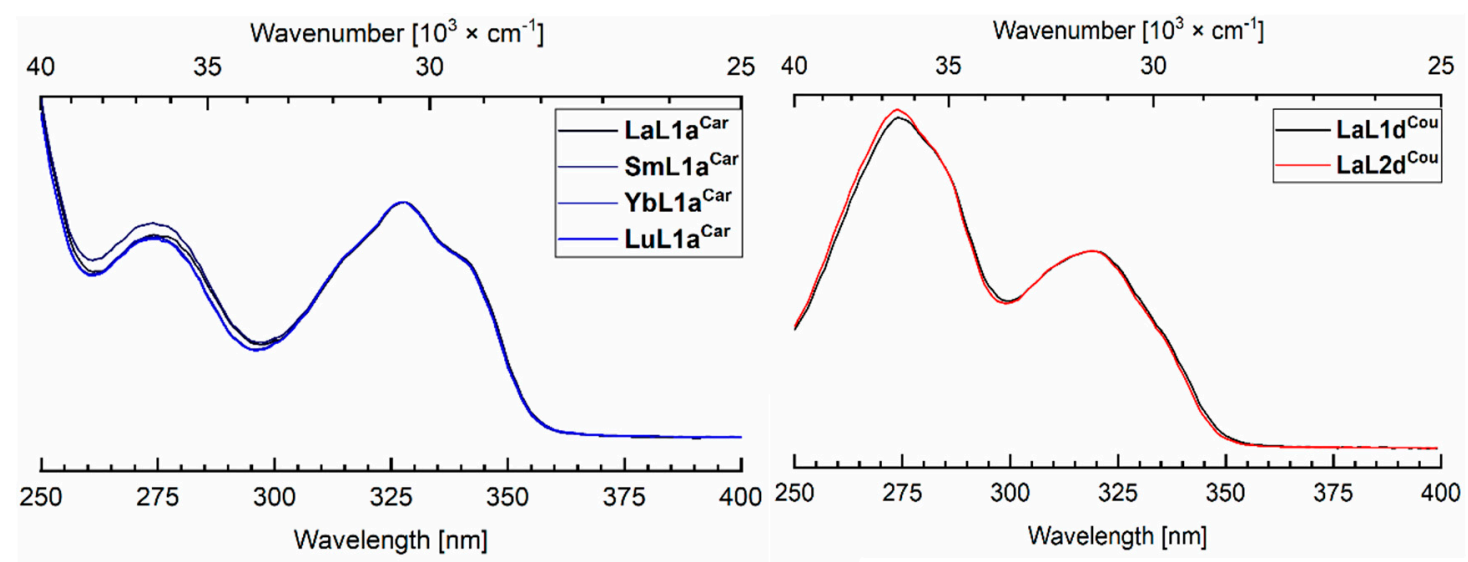

Figure 5. Superimposed UV-Vis absorption spectra of $\operatorname{LnL1a}^{\mathrm{Car}}(\mathrm{Ln}=\mathrm{La}, \mathrm{Sm}, \mathrm{Yb}, \mathrm{Lu})$ (left) and LaL1d ${ }^{\text {Cou }}$ and LaL2d ${ }^{\text {Cou }}$ (right) complexes normalized at $328 \mathrm{~nm}$ and $319 \mathrm{~nm}$, respectively. $[\mathbf{L n L}]=10 \mu \mathrm{M}$ and was measured in aqueous $10 \mathrm{mM}$ PIPES buffer at $\mathrm{pH}$ 6.5.

The triplet levels of the carbostyril and coumarin antennae were determined from the steady-state emission spectra of the Gd(III) complexes at $77 \mathrm{~K}$ upon excitation at $\lambda_{\mathrm{ex}}=327$ and $315 \mathrm{~nm}$, respectively (Figure S44). The triplet excited state $\left(\mathrm{T}_{1}\right)$ of carbostyril was located at $23,000 \mathrm{~cm}^{-1}$, while that of the coumarin was found at slightly lower energies, and $22,200 \mathrm{~cm}^{-1}$. These values were determined from the 0-0 phonon transitions. The energies of both types of antennae were expected to be suitable for sensitization of $\mathrm{Tb}(\mathrm{III}), \mathrm{Eu}(\mathrm{III})$ and $\mathrm{Sm}(\mathrm{III})$, with excited states at $20,600\left({ }^{5} \mathrm{D}_{4}\right), 17,300\left({ }^{5} \mathrm{D}_{0}\right)$ and 18,000 
$\left({ }^{4} \mathrm{G}_{5 / 2}\right) \mathrm{cm}^{-1}$ [37], respectively. As the coumarin $\mathrm{T}_{1}$ is within $\sim 2000 \mathrm{~cm}^{-1}$ of the $\mathrm{Tb}$ (III) excited state, back energy transfer from $\mathrm{Tb}$ (III) to $\mathrm{T}_{1}$ was considered a possibility.

Antenna excitation at $\lambda_{\mathrm{ex}}=327$ or $315 \mathrm{~nm}$ yielded $\mathrm{Ln}(\mathrm{III})$-centered emission $(\mathrm{Ln}=\mathrm{Eu}, \mathrm{Tb}$ and $\mathrm{Sm}$ ) (Figures 6 and 7, Table 2) with all four ligands. The emission spectra along with the assignment of the peaks are shown in Figures 6 and 7. Varying amounts of residual antenna fluorescence were also seen at $\lambda_{\mathrm{em}}=375$ and $385 \mathrm{~nm}$ in the carbostyril and the coumarin-sensitized complexes, respectively. The ligand fluorescence quantum yield $\left(\Phi_{\mathrm{L}}\right)$ of EuL2a ${ }^{\mathrm{Car}}$ was 3.2 times lower than that of EuL1aCar In both $\mathrm{Eu}(\mathrm{III})$ triamide and tricarboxylate complexes carrying the coumarin antenna $\Phi_{\mathrm{L}}$ was $\sim 0.60 \%$. The new Eu and $\mathrm{Tb}$ complexes had lower $\mathrm{Ln}(\mathrm{III})$ emission quantum yields $\left(\Phi_{\mathrm{Ln}}\right)$ than the previously reported $\mathbf{L n L 1 a}{ }^{C a r}$. In the case of $\mathbf{L n L 2 a}{ }^{C a r}$ the lower $\Phi_{\mathrm{Ln}}$ is due to the replacement of the tricarboxylate metal-binding fragment with the triamide one. The latter places $6 \mathrm{~N}-\mathrm{H}$ oscillators close to the $\mathrm{Ln}(\mathrm{III})$, which quenches some of the $\mathrm{Ln}(\mathrm{III})$ emission. PeT quenching is more efficient for more electron-rich antennae [20] and for more reducible $\mathrm{Eu}$ (III) ions [30,36]. As Eu(III) in EuL2aCar is easier to reduce than in EuL1aCar, PeT quenching might be more prominent in the former. This suggestion is supported by the significantly smaller $\Phi_{\mathrm{L}}$ value of EuL2a ${ }^{\mathrm{Car}}$ compared to that of EuL1aCar. $\Phi_{\mathrm{Ln}}$ of SmL1a ${ }^{\mathrm{Car}}$ and SmL2aCar were similar to those obtained for Sm(III) emitters sensitized by secondary amide-linked carbostyril antennae [20].

The coumarin-sensitized complexes were less emissive than their carbostyril analogues (Table 2) irrespective of the $\mathrm{Ln}(\mathrm{III})$. For $\mathrm{Ln}=\mathrm{Tb}$ this may be due to the oxygen sensitivity of the excited complex. However, for $\mathrm{Eu}(\mathrm{III})$, the reason is less obvious. The coumarin $\mathrm{T}_{1}$ is well-placed for energy transfer to the $\mathrm{Eu}(\mathrm{III}){ }^{5} \mathrm{D}_{2}\left(21500 \mathrm{~cm}^{-1}\right)$ level. Based on the work of Latva, this antenna should provide excellent sensitization [38]. The $\Phi_{\mathrm{L}}$ data do not indicate that there is either PeT quenching of the excited state or direct energy transfer from antenna singlet level $\left(\mathrm{S}_{1}\right)$, as the $\Phi_{\mathrm{L}}$ for the coumarin-sensitized complexes are similar irrespective of the $\mathrm{Ln}(\mathrm{III})$ and the type of metal binding site.

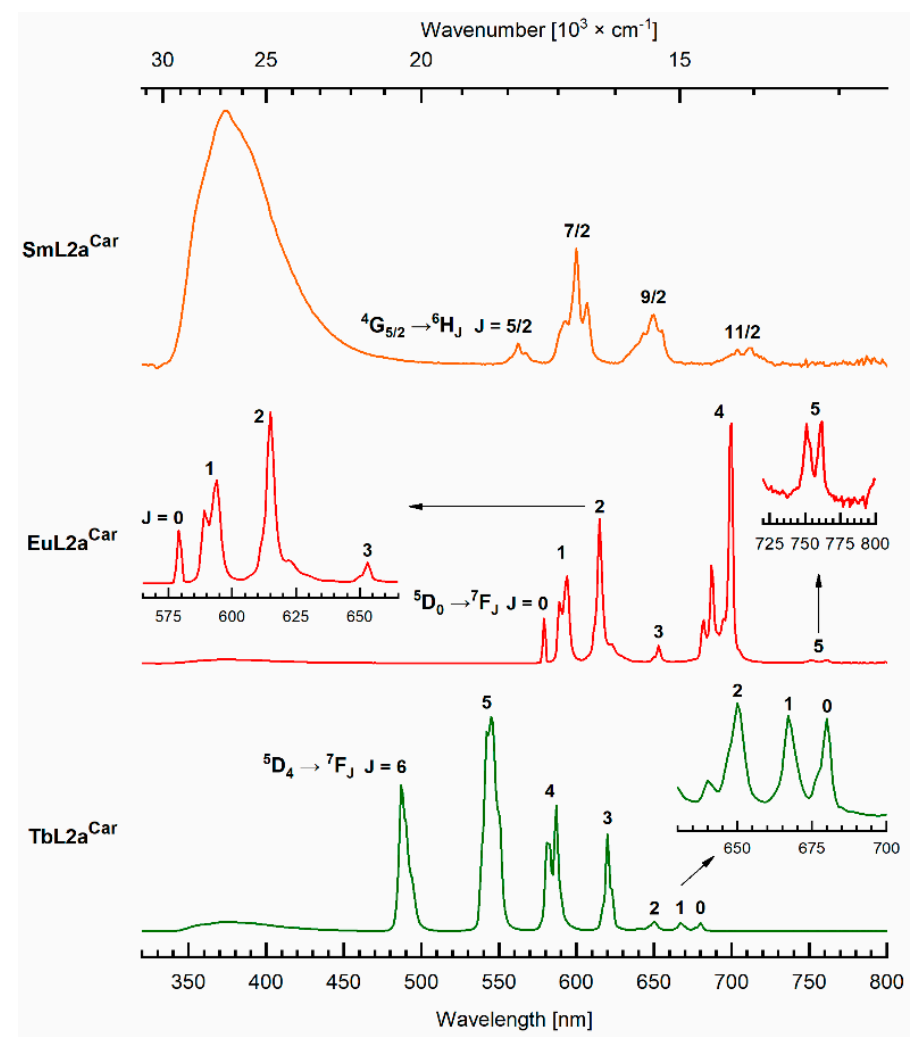

Figure 6. Steady-state emission spectra of SmL2aCar (top, orange), EuL2a ${ }^{C a r}$ (middle, red) and TbL2aCar (bottom, green) complexes. [LnL2aCar] $=10 \mu \mathrm{M}$ and was measured in $\mathrm{D}_{2} \mathrm{O}(\mathrm{Ln}=\mathrm{Sm}$ and Eu) or aqueous $(\mathrm{Ln}=\mathrm{Tb}) 10 \mathrm{mM}$ PIPES buffer solutions $(10 \mathrm{mM})$ at $\mathrm{pH}(\mathrm{pD}) 6.5$ with $\lambda_{\mathrm{ex}}=327 \mathrm{~nm}$. 
Secondary amide-linked carbostyril complexes have previously been shown to sensitize $\mathrm{Yb}$ (III) emission [20]. The $\mathrm{Yb}$ (III) complexes of the new ligands with tertiary amide linkers were prepared, and their luminescence spectra in the near infrared were recorded. While the sensitivity of the instrument available to us has decreased considerably over the past years (Figures S56 and S57), the relative emission intensities of the previously reported complexes [20] could be compared to those of YbL1aCar or $\mathrm{YbL2a}^{\mathrm{Car}}$ and $\mathrm{YbL1d}^{\mathrm{Cou}}$ or YbL2d ${ }^{\mathrm{Cou}}$ (Figure S58). Only very weak emission was observed for $\mathbf{Y b L 1 d}^{\mathrm{Cou}}$ and YbL2d ${ }^{\mathrm{Cou}}$, much weaker than for either the secondary or the tertiary amide-linked carbostyril-sensitized species. As the most likely sensitization pathway in these emitters is via PeT-back electron transfer [30], these data are in line with an inefficient PeT in the coumarin-carrying complexes.

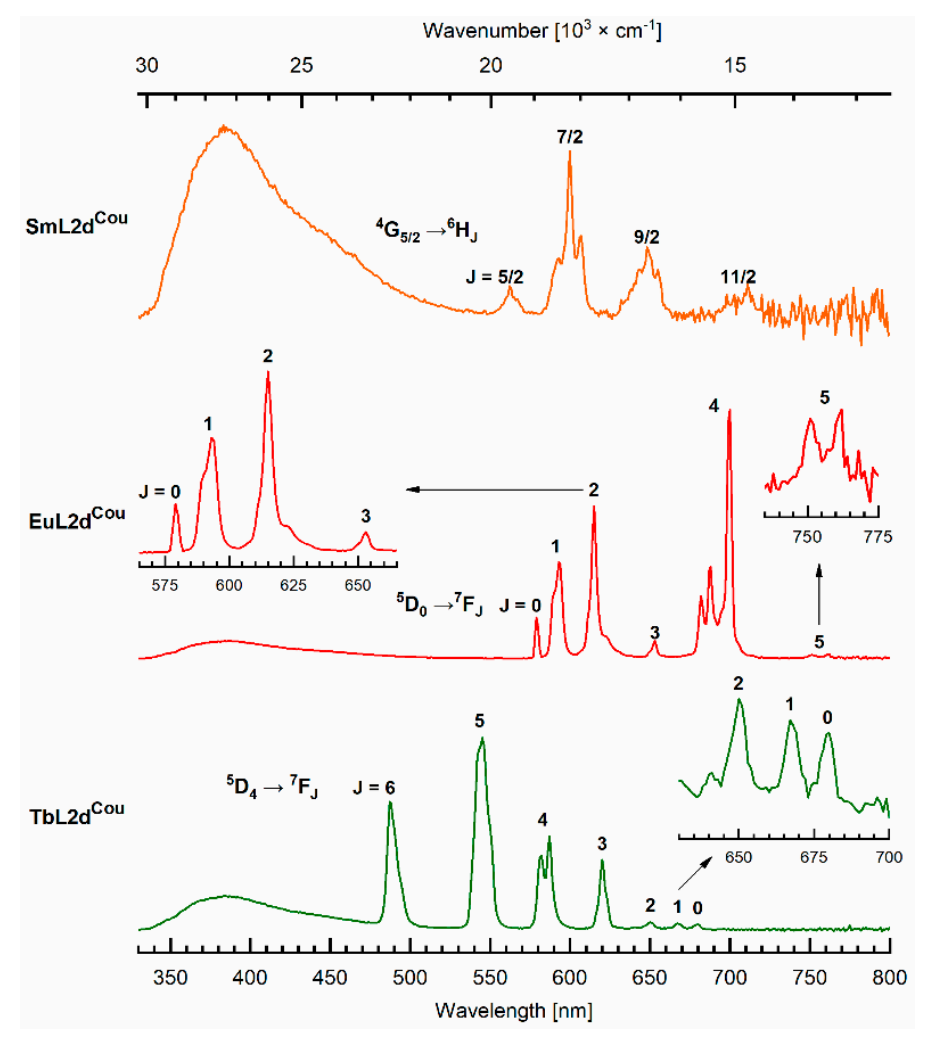

Figure 7. Steady-state emission spectra of SmL2d Cou (top, orange), EuL2d Cou (middle, red) and TbL2d ${ }^{\mathrm{Cou}}$ (bottom, green) complexes. [LnL2d $\left.{ }^{\mathrm{Cou}}\right]=10 \mu \mathrm{M}$ and was measured in $\mathrm{D}_{2} \mathrm{O}(\mathrm{Ln}=\mathrm{Sm})$ or aqueous $(\mathrm{Ln}=\mathrm{Eu}$ and $\mathrm{Tb}) 10 \mathrm{mM}$ PIPES buffer solutions $(10 \mathrm{mM})$ at $\mathrm{pH}(\mathrm{pD}) 6.5$ with $\lambda_{\mathrm{ex}}=315 \mathrm{~nm}$.

Table 2. Antenna- and Ln(III)-based luminescence quantum yields, Ln(III) lifetimes and hydration states of LnL.

\begin{tabular}{|c|c|c|c|c|c|}
\hline Complex & $\Phi_{\mathrm{L}}[\%]^{[a]}$ & $\Phi_{\mathrm{Ln}}[\%]^{[\mathrm{a}]}$ & $\tau_{\mathrm{H} 2 \mathrm{O}}[\mathrm{ms}]$ & $\tau_{\mathrm{D} 2 \mathrm{O}}[\mathrm{ms}]$ & $q^{[\mathrm{b}]}$ \\
\hline LaL1a $^{\text {Car }}$ & 4.9 & - & - & - & - \\
\hline SmL1aCar & $3.6^{[\mathrm{c}]}$ & $0.19^{[\mathrm{c}]}$ & 0.009 & 0.032 & - \\
\hline EuL1aCar $[d]$ & 2.5 & 8.9 & 0.66 & 2.17 & 1.0 \\
\hline GdL1a $^{\text {Car }[\mathrm{d}]}$ & 5.1 & - & - & - & - \\
\hline TbL1aCar $[\mathrm{d}]$ & 4.5 & 45.1 & 1.81 & 2.92 & 0.8 \\
\hline YbL1aCar & 4.5 & - & - & - & - \\
\hline $\mathrm{LuL1a}^{\mathrm{Car}}$ & 4.7 & - & - & - & - \\
\hline $\mathrm{LaL2a}$ Car & 4.1 & - & - & - & - \\
\hline SmL2aCar & $3.4^{[c]}$ & $0.21^{[c]}$ & 0.010 & 0.032 & - \\
\hline EuL2a $a^{C a r}$ & $0.77^{[\mathrm{e}]}$ & $2.7^{[\mathrm{e}]}$ & 0.51 & 2.05 & 0.9 \\
\hline GdL2aCar & $4.3^{[c]}$ & - & - & - & - \\
\hline
\end{tabular}


Table 2. Cont.

\begin{tabular}{|c|c|c|c|c|c|}
\hline Complex & $\Phi_{\mathrm{L}}[\%]^{[\mathrm{a}]}$ & $\Phi_{\text {Ln }}[\%]^{[a]}$ & $\tau_{\mathrm{H} 2 \mathrm{O}}[\mathrm{ms}]$ & $\tau_{\mathrm{D} 2 \mathrm{O}}[\mathrm{ms}]$ & $q^{[\mathrm{b}]}$ \\
\hline TbL2aCar & 4.1 & 36.6 & 1.50 & 2.70 & 1.2 \\
\hline YbL2aCar & 4.3 & - & - & - & - \\
\hline LuL2aCar & 4.5 & - & - & - & - \\
\hline LaL1d $^{\mathrm{Cou}}$ & 0.66 & - & - & - & - \\
\hline SmL1d ${ }^{\text {Cou }}$ & $0.64[\mathrm{c}]$ & 0.059 [c] & 0.010 & 0.031 & - \\
\hline EuL1d Cou & $0.62^{[\mathrm{e}]}$ & $2.2^{[\mathrm{e}]}$ & 0.62 & 1.96 & 1.0 \\
\hline GdL1d $^{\text {Cou }}$ & $0.66^{[c]}$ & - & - & - & - \\
\hline TbL1d $^{\text {Cou }}$ & 0.62 & 1.7 & 0.47 & 0.61 & - \\
\hline YbL1d Cou & 0.66 & - & - & - & - \\
\hline LuL1d Cou & 0.64 & - & - & - & - \\
\hline LaL2d $d^{C o u}$ & 0.66 & - & - & - & - \\
\hline SmL2d ${ }^{\text {Cou }}$ & $0.64^{[c]}$ & $0.067^{[\mathrm{c}]}$ & 0.012 & 0.032 & - \\
\hline EuL2d Cou & $0.58^{[\mathrm{e}]}$ & $1.5^{[\mathrm{e}]}$ & 0.54 & 2.01 & 0.8 \\
\hline GdL2d Cou & $0.63^{[c]}$ & - & - & - & - \\
\hline $\mathrm{TbL2d}$ Cou & 0.67 & 1.0 & 0.29 & 0.45 & - \\
\hline $\mathrm{YbL} \mathrm{d}^{\mathrm{Cou}}$ & 0.57 & - & - & - & - \\
\hline LuL2d Cou & 0.61 & - & - & - & - \\
\hline
\end{tabular}

Measurements were performed with [LnL] $=10 \mu \mathrm{M}$ in $10 \mathrm{mM}$ aqueous PIPES buffer solutions at $\mathrm{pH}(\mathrm{pD}) 6.5$. [a] Relative to quinine sulfate $(\Phi=0.59)$ in $\mathrm{H}_{2} \mathrm{SO}_{4}(0.05 \mathrm{M})$ [39]. ${ }^{[b]}$ Calculated using the Equation $q=5\left(1 / \tau_{\mathrm{H} 2 \mathrm{O}}-1 / \tau_{\mathrm{D} 2 \mathrm{O}}\right.$ - 0.06) for $\mathrm{Tb}$, and $q=1.2\left(1 / \tau_{\mathrm{H} 2 \mathrm{O}}-1 / \tau_{\mathrm{D} 2 \mathrm{O}}-0.25-n \times 0.075\right)$, where $\mathrm{n}$ is the number of nearby N-H oscillators, for Eu [18]. [c] Mean for two independent measurements. ${ }^{[\mathrm{d}]}$ Data from [19]. [e] Mean for three independent measurements.

The Ln(III) luminescence lifetimes $(\tau)$ were measured using time-resolved emission spectroscopy. In PIPES-buffered aqueous solutions the triamide-based $\mathrm{Eu}(\mathrm{III})$ complexes had $\tau_{\mathrm{H} 2 \mathrm{O}}$ between 0.51-0.54 ms (Table 3); the lifetimes of the tricarboxylates increased to $0.62-0.66 \mathrm{~ms}$ due to the absence of the quenching amide N-H oscillators. The Tb(III) lifetimes in TbL1aCar and TbL2aCar ${ }^{\text {were } 1.81 ~ m s ~}$ and $1.50 \mathrm{~ms}$, respectively. In the coumarin-sensitized $\mathrm{Tb}(\mathrm{III})$ complexes $\tau_{\mathrm{H} 2 \mathrm{O}}$ was much shorter. This is likely due to the oxygen-sensitivity of these emissions, which also precluded the determination of the hydration states $(q)$ of $\mathbf{T b L 1 d} \mathbf{d o u}^{\mathrm{Cou}}$ and TbL2d $\mathbf{d}^{\mathrm{Cou}}$. For the other $\mathrm{Eu}(\mathrm{III})$ and $\mathrm{Tb}(\mathrm{III})$ complexes, $q$ was found to be $\sim 1$ using the Horrocks $[17,40]$ and Beeby [18] method. This value is in accordance with the octadentate ligand structure and the nine-coordinate environment of Eu(III) and Tb(III). The Sm(III) lifetimes were unsurprisingly short, around $10 \mu \mathrm{s}$. These lifetimes are similar to what was previously obtained for Sm(III) emitters in DO3A-type ligands [20].

The reason for the low $\Phi_{\mathrm{Ln}}$ of EuL1d ${ }^{\text {Cou }}$ and EuL2d ${ }^{\text {Cou }}$ was next investigated by an analysis of the Eu(III) luminescence spectra. Sensitized Ln(III) emission is the product of multiple processes: photon absorption by the antenna, energy transfer from the antenna to the Ln(III), and Ln(III) luminescence. For $\mathrm{Eu}(\mathrm{III})$, it is possible to obtain information on the processes leading to the excited Ln(III) using Equations (1) and (2) [41,42]. The overall luminescence intensity $\left(\Phi_{\mathrm{Ln}}\right)$ is a product of the luminescent decay of the excited Ln(III), quantified by its intrinsic quantum yield ( $\left.\Phi_{\mathrm{Ln}}^{\mathrm{Ln}}\right)$, and of the sensitization efficiency ( $\left.\eta_{\text {sens }}\right)$, i.e., the efficiency with which the $\mathrm{Ln}(\mathrm{III})$ excited state is populated. $\Phi_{\mathrm{Ln}}^{\mathrm{Ln}}$ is the ratio of the observed and radiative luminescence lifetimes ( $\tau_{\mathrm{obs}}$ and $\tau_{\text {rad }}$, respectively). The latter for $\mathrm{Eu}(\mathrm{III})$ can be calculated from the luminescence spectrum using Equation (1), where $A_{\mathrm{MD}, 0}$ is the spontaneous emission probability for the ${ }^{5} \mathrm{D}_{0} \rightarrow{ }^{7} \mathrm{~F}_{1}$ transition of $\mathrm{Eu}(\mathrm{III})$ in vacuo with a value of $14.65 \mathrm{~s}^{-1}, n$ is the refractive index of the medium (1.333 for $\mathrm{H}_{2} \mathrm{O}$ [43] and 1.328 for $\mathrm{D}_{2} \mathrm{O}$ [44]), and $I_{\text {tot }}$ and $I_{\mathrm{MD}}$ are the total corrected Eu(III) emission spectrum (521-800 nm) and the ${ }^{5} \mathrm{D}_{0} \rightarrow{ }^{7} \mathrm{~F}_{1}$ band (582-603 nm), respectively [42]. The obtained values are summarized in Table 3.

$\Phi_{\mathrm{Ln}}^{\mathrm{Ln}}$ quantifies the extent to which the excited $\mathrm{Ln}(\mathrm{III})$ can emit in the given coordination environment; similar values were obtained for both types of complexes in $\mathrm{H}_{2} \mathrm{O}$ and $\mathrm{D}_{2} \mathrm{O}$. Clearly, the difference in $\Phi_{\mathrm{Eu}}$ for the four Eu(III) emitters is primarily down to differences in $\eta_{\text {sens. The highest }}$ $\eta_{\text {sens }}$ is obtained for EuL1aCar, and the second highest for EuL2aCar. The lower $\eta_{\text {sens }}$ of EuL2aCar is likely due to a combination of PeT and also possibly the quenching of the antenna by the amide $\mathrm{N}-\mathrm{H}$ 
oscillators. The latter, along with solvent quenching of the antenna, can be eliminated by determining $\eta_{\text {sens }}$ in $\mathrm{D}_{2} \mathrm{O}$ (Table 3 ). Solvent deuteration does indeed result in a small increase in $\eta_{\text {sens }}$ across the board. The differences in $\eta_{\text {sens }}$ between the EuL1a ${ }^{\text {Car }}$ (80.3\%) and EuL2aCar $(29.8 \%)$, on the one hand, and their coumarin analogues EuL1d ${ }^{\text {Cou }}(23.0 \%)$ and EuL2d ${ }^{\text {Cou }}(16.0 \%)$, on the other, remain large.

$$
\begin{gathered}
\frac{1}{\tau_{\mathrm{rad}}}=A_{\mathrm{MD}, 0} \times n^{3}\left(\frac{I_{\mathrm{tot}}}{I_{\mathrm{MD}}}\right) \\
\Phi_{\mathrm{Ln}}=\eta_{\mathrm{sens}} \cdot \Phi_{\mathrm{Ln}}^{\mathrm{Ln}}=\eta_{\mathrm{sens}} \cdot \frac{\tau_{\mathrm{obs}}}{\tau_{\mathrm{rad}}}
\end{gathered}
$$

\begin{tabular}{|c|c|c|c|c|c|c|c|c|}
\hline Complex & $\tau_{\text {rad,Ln }}{ }^{[b]}$ & $\Phi_{\operatorname{Ln}}^{\operatorname{Ln}[c]}$ & $\eta_{\text {sens }}{ }^{[c]}$ & $\Phi_{\mathrm{L}, \mathrm{D} 2 \mathrm{O}}{ }^{[\mathrm{d}]}$ & $\Phi_{\text {Ln,D2O }}{ }^{[\mathrm{d}]}$ & $\tau_{\mathrm{rad}, \mathrm{Ln}}\left(\mathrm{D}_{2} \mathrm{O}\right)^{[\mathrm{e}]}$ & $\Phi_{\operatorname{Ln}}^{\operatorname{Ln}}\left(D_{2} O\right)^{[f]}$ & $\eta_{\text {sens }}\left(D_{2} \mathrm{O}\right)^{[f]}$ \\
\hline EuL2aCar & 5.11 & 10.0 & 27.6 & $0.83(1.08)$ & $11.8(4.2)$ & 5.16 & $39.7(3.97)$ & $29.8(1.08)$ \\
\hline EuL2d Cou & 5.03 & 10.7 & 14.1 & $0.60(1.03)$ & $6.3(4.2)$ & 5.11 & $39.3(3.67)$ & $16.0(1.14)$ \\
\hline
\end{tabular}

Table 3. Photophysical properties of EuL in PIPES-buffered $\mathrm{H}_{2} \mathrm{O}$ and $\mathrm{D}_{2} \mathrm{O}$ solutions ${ }^{[a]}$.

${ }^{[a]}[\mathrm{LnL}]=10 \mu \mathrm{M}$ in $10 \mathrm{mM}$ aqueous PIPES buffer $\mathrm{H}_{2} \mathrm{O}$ or $\mathrm{D}_{2} \mathrm{O}$ solutions at $\mathrm{pH}(\mathrm{pD})$ 6.5. ${ }^{\text {[b] }}$ In ms, determined using Equation (1). ${ }^{[c]}$ In \%, determined using Equation (2). ${ }^{[\mathrm{d}]} \mathrm{In} \%$, relative to quinine sulfate $(\Phi=0.59)$ in $\mathrm{H}_{2} \mathrm{SO}_{4}$ $(0.05 \mathrm{M})$ [39]. [e] In ms, determined using Equation (1). [f] In \%, determined using Equation (2), in parentheses change relative to the solution in $\mathrm{H}_{2} \mathrm{O}$.

The addition of external fluoride to a solution of EuL2 $\mathbf{b}^{\text {Car }}$ was shown to increase $\Phi_{\text {Eu }}$ up to 7.6-fold [36]. Most of this increase could be ascribed to Eu(III) stabilization by the negatively charged $\mathrm{F}^{-}$ ligand, which reduced PeT quenching. This was apparent from the 3.35-fold larger $\eta_{\text {sens }}$ in the presence of KF compared to $\eta_{\text {sens }}$ without KF. To evaluate the cause of the low $\eta_{\text {sens }}$ in EuL1d Cou and EuL2d Cou their photophysical properties in the presence of a large excess of KF (EuL-F) in PIPES-buffered $\mathrm{H}_{2} \mathrm{O}$ (Table 4) and $\mathrm{D}_{2} \mathrm{O}$ (Table 5) solutions were determined.

KF addition increased $\Phi_{\mathrm{L}}$ and $\Phi_{\mathrm{Eu}} 2.73$-fold and 4.56-fold in the case of triamide EuL2aCar $-\mathrm{F}$. This increase was somewhat smaller than seen for the secondary amide EuL2 $\mathbf{b}^{\text {Car }}$-F, suggesting that PeT quenching was smaller in former. The increase in $\Phi_{\mathrm{L}}$ and $\Phi_{\mathrm{Eu}}$ in the case of EuL1aCar-F was negligible, either because PeT quenching in the absence of fluoride was already small, or because fluoride binding was ineffective due to the overall -1 charge of the complex. The absence of fluoride binding was supported by the fact that the EuL1a ${ }^{\text {Car }}-\mathbf{F}$ and EuL1d ${ }^{\text {Cou }}-\mathbf{F}$ both retained their water ligand and had $q=1$ (Figures S63 and S65). EuL2aCar-F and EuL2d ${ }^{\text {Cou }}$-F on the other hand had $q=0$, which is in accordance with the presence of a fluoride ligand instead of a water molecule (Table S28, Figures S64 and S66).

Fluoride binding increased $\Phi_{\mathrm{Eu}}$ in EuL2d ${ }^{\text {Cou }}$-F 2.2-fold. This increase was ascribable to an improved intrinsic quantum yield (1.96-fold increase), which in turn was caused by the removal of the inner-sphere water molecule $(q=0)$. Changes in $\Phi_{\mathrm{L}}$ and $\eta_{\text {sens }}$ were negligible, which suggests that the low $\Phi_{\mathrm{Eu}}$ in EuL2d ${ }^{\text {Cou }}$ was not due to PeT quenching.

When fluoride addition was carried out in $\mathrm{D}_{2} \mathrm{O}, \sim 2.6$-fold higher $\Phi_{\mathrm{Eu}}$ was recorded for the triamide complexes compared to what was obtained in $\mathrm{H}_{2} \mathrm{O}$. For the tricarboxylates, the increase was on average 3.5-fold. These changes are consistent with the removal of outer-sphere $\mathrm{X}-\mathrm{H}$ oscillators, as shown by a comparable increase in the intrinsic quantum yields. The greater $\Phi_{\mathrm{Eu}}$ increase for EuL1 further supports the hypothesis that fluoride does not bind to these Eu(III) centers, and thus, X-H oscillators are only removed by deuteration rather than ligand exchange.

Having excluded PeT quenching as the major cause of the low $\eta_{\text {sens }}$, poor energy transfer efficiency and inefficient population of the antenna feeding levels remain as possible alternatives. While these were not investigated in depth, we note that the steady-state and time-resolved emission spectra of $\mathrm{Eu}(\mathrm{III})$ complexes at $77 \mathrm{~K}$ did not contain the triplet emission bands from the antennae (Figure S71). This indicates that $\mathrm{T}_{1}$ was quenched in these complexes, possibly by energy transfer to Eu(III). 
Table 4. Photophysical properties of EuL-F in PIPES-buffered $\mathrm{H}_{2} \mathrm{O}$ [a]

\begin{tabular}{|c|c|c|c|c|c|c|}
\hline Complex & $\Phi_{\mathrm{L}}[\%]^{[b]}$ & $\Phi_{\text {Ln }}[\%]^{[b]}$ & $\tau_{\mathrm{rad}, \mathrm{Ln}}[\mathrm{c}]$ & $\tau_{\text {obs }}[\mathrm{ms}]$ & $\Phi_{\operatorname{Ln}}^{\operatorname{Ln}[d]}$ & $\eta_{\text {sens }}[\mathrm{e}]$ \\
\hline EuL1aCar $_{-F}$ & 2.5 & $9.5(\times 1.07)$ & 5.33 & 0.68 & $12.8(\times 1.05)$ & 73.4 (1.01) \\
\hline EuL2aCar $-F$ & $2.1(\times 2.73)$ & $12.3(\times 4.56)$ & 4.86 & 1.01 & $20.7(\times 2.07)$ & $58.9(2.13)$ \\
\hline $\mathrm{EuL1d}^{\mathrm{Cou}}-\mathrm{F}$ & $0.64(\times 1.03)$ & $2.3(\times 1.10)$ & 5.19 & 0.69 & $13.3(\times 1.14)$ & $17.3(0.98)$ \\
\hline $\mathrm{EuL2d}^{\mathrm{Cou}}-\mathrm{F}$ & $0.65(\times 1.12)$ & $3.3(\times 2.20)$ & 4.81 & 1.01 & $21.0(\times 1.96)$ & $15.7(1.12)$ \\
\hline
\end{tabular}

${ }^{\text {[a] }}$ Formed by the addition of excess KF $\left(0.1 \mathrm{M}, 10^{4}\right.$-fold excess) to a solution of EuL. [EuL] $=10 \mu \mathrm{M}$ in $10 \mathrm{mM}$ aqueous PIPES buffer solutions at pH 6.5. In parentheses fold increase compared to EuL without added KF. [b] Relative to quinine sulfate $(\Phi=0.59)$ in $\mathrm{H}_{2} \mathrm{SO}_{4}(0.05 \mathrm{M})$ [39]. ${ }^{[c]}$ In ms, determined using Equation (1). ${ }^{[\mathrm{d}]}$ In \%, determined using Equation (2). ${ }^{[\mathrm{e}]}$ In \%, determined using Equation (2).

Table 5. Antenna- and Eu(III)-based luminescence properties of EuL-F in PIPES-buffered $\mathrm{D}_{2} \mathrm{O}$ solution ${ }^{\text {[a] }}$.

\begin{tabular}{|c|c|c|c|c|c|c|}
\hline Complex & $\Phi_{\mathrm{L}}[\%]^{[\mathrm{b}]}$ & $\Phi_{\text {Ln }}[\%]^{[b]}$ & $\tau_{\mathrm{rad}, \mathrm{Ln}}{ }^{[\mathrm{c}]}$ & $\tau_{\mathrm{obs}}[\mathrm{ms}]$ & $\Phi_{\operatorname{Ln}}^{\operatorname{Ln}[d]}$ & $\eta_{\text {sens }}[\mathrm{e}]$ \\
\hline EuL1aCar $_{-F}$ & $2.6(1.04)$ & $32.3(3.4)$ & 5.38 & 2.29 & $42.6(3.33)$ & 75.7 (1.03) \\
\hline $\mathrm{EuL}_{2} \mathrm{a}^{\mathrm{Car}}-\mathrm{F}$ & $2.2(1.05)$ & $31.3(2.6)$ & 4.89 & 2.40 & $49.1(2.37)$ & $63.7(1.08)$ \\
\hline EuL1d $^{\text {Cou }}-\mathrm{F}$ & $0.67(1.06)$ & $8.2(3.6)$ & 5.29 & 2.25 & $42.6(3.20)$ & $19.2(1.11)$ \\
\hline $\mathrm{EuL2d}^{\mathrm{Cou}}-\mathrm{F}$ & $0.69(1.08)$ & $8.7(2.6)$ & 4.88 & 2.39 & $48.9(2.33)$ & $17.8(1.13)$ \\
\hline
\end{tabular}

${ }^{\text {[a] }}$ Formed by the addition of KF $\left(0.1 \mathrm{M}, 10^{4}\right.$-fold excess) to a solution of EuL. [EuL] $=10 \mu \mathrm{M}$ in $10 \mathrm{mM}$ PIPES buffer solutions in $\mathrm{D}_{2} \mathrm{O}$ at $\mathrm{pD}$ 6.5. In parentheses: fold increase relative to the solution in $\mathrm{H}_{2} \mathrm{O}$. ${ }^{[\mathrm{b}]}$ Relative to quinine sulfate $(\Phi=0.59)$ in $\mathrm{H}_{2} \mathrm{SO}_{4}(0.05 \mathrm{M})$ [39]. [c] In ms, determined using Equation (1). [d] $\mathrm{In} \%$, determined using Equation (2). ${ }^{[\mathrm{e}]}$ In \%, determined using Equation (2).

\section{Materials and Methods}

\subsection{General Procedures}

${ }^{1} \mathrm{H}$ NMR (400 MHz), ${ }^{13} \mathrm{C}$ NMR (100 MHz) and ${ }^{19} \mathrm{~F}$ NMR (376 MHz) spectra were recorded on a JEOL $400 \mathrm{MHz}$ instrument (JEOL RESONANCE Inc., Tokyo, Japan). Chemical shifts were referenced to residual solvent peaks and are given as follows: chemical shift $(\delta, \mathrm{ppm})$, multiplicity (s, singlet; br, broad; $d$, doublet, $t$, triplet; $q$, quartet; $m$, multiplet), coupling constant (Hz), integration. LC-MS analysis was carried out using an analytical Dionex UltiMate 3000 HPLC instrument (Dionex Softron $\mathrm{GmbH}$, Germering, Germany) coupled to a Thermo Finnigan LCQ DECA XP MAX mass spectrometer (Thermo ELECTRON CORPORATION, San Jose, CA, USA). HR-ESI-MS analyses were performed at the Organisch Chemisches Institut WWU Münster, Germany or at the Stenhagen Analyslab AB, Mölndal, Sweden. All compounds displayed the expected isotope distribution pattern. Anhydrous $\mathrm{CH}_{2} \mathrm{Cl}_{2}$ was obtained by distillation from $\mathrm{CaH}_{2}$ under an Ar atmosphere.

Compounds 1 [19], 6 [19], L1aCar [19], LnL1aCar $(\mathrm{Ln}=\mathrm{Eu}, \mathrm{Gd}, \mathrm{Tb})$ [19] and L1d $^{\mathrm{Cou}}$ [20] were synthesized following literature methods. All other chemicals were from commercial sources (Sigma Aldrich, St. Louis, MO, USA or Fluorochem, Hadfield, UK) and used as received.

\subsection{Paramagnetic ${ }^{1} H N M R$}

${ }^{1} \mathrm{H}$ NMR spectra of Eu complexes were recorded at $400 \mathrm{MHz}$ using the following parameters: cooling for $5 \mathrm{~min}$ until the temperature stabilizes at $0 \pm 0.1^{\circ} \mathrm{C}$ for samples measured in $\mathrm{CD}_{3} \mathrm{OD}$ and at $10 \pm 0.1{ }^{\circ} \mathrm{C}$ for samples measured in $\mathrm{D}_{2} \mathrm{O}$; relaxation delay: $1 \mathrm{~s}$; number of scans: 128 ; number of points: 131,072; range: -60 to $60 \mathrm{ppm}$. For $\mathrm{Yb}$ complexes measured at r.t. the number of points were 524,288 and the range was from -240 to $240 \mathrm{ppm}$.

\subsection{Chromatography}

Preparative chromatography was carried out on silica gel [Normasil 60 chromatographic silica media (40-63 micron)] and aluminum oxide [activated, neutral, Brockmann Activity I, Sigma-Aldrich (Sigma Aldrich, St. Louis, MO, USA)]. Thin layer chromatography was performed on silica-coated (60G F254) glass plates from Merck and aluminum oxide coated with $254 \mathrm{~nm}$ fluorescent indicator 
aluminum plates from Sigma-Aldrich. Samples were visualized by UV-light (UVP LLC, Upland, CA, USA) (254 and $365 \mathrm{~nm}$ ).

HPLC-analysis was performed on a Dionex UltiMate 3000 system (Dionex Softron GmbH, Germering, Germany) using a Phenomenex Gemini ${ }^{\circledR}$ C18 TMS end-capped $150 \mathrm{~mm} \times 4.6 \mathrm{~mm}$ HPLC column with HPLC water ( $0.05 \%$ formic acid): $\mathrm{CH}_{3} \mathrm{CN}$ (0.05\% formic acid) eluent system using the methods: (a) $0-8 \mathrm{~min}: 10 \rightarrow 20 \%$ and $8-12 \mathrm{~min}: 20 \%$ iso and $12-16 \mathrm{~min} 20 \rightarrow 90 \% \mathrm{CH}_{3} \mathrm{CN}, 0.5 \mathrm{~mL} / \mathrm{min}$; (b) 0-8 $\mathrm{min}$ : $10 \%$ iso and $8-12 \mathrm{~min}: 10 \% \rightarrow 50 \%$ and $12-16 \mathrm{~min} 50 \% \rightarrow 90 \% \mathrm{CH}_{3} \mathrm{CN}, 0.25 \mathrm{~mL} / \mathrm{min}$. UV-Vis (UltiMate 3000 Photodiode Array Detector (Dionex Softron GmbH, Germering, Germany)) and ESI-MS detections (Thermo Finnigan LCQ DECA XP MAX (Thermo ELECTRON CORPORATION, San Jose, CA, USA)) were used. Semi-preparative HPLC was performed on Dionex UltiMate 3000 system (Dionex Softron $\mathrm{GmbH}$, Germering, Germany) using a Phenomenex Gemini ${ }^{\circledR}$ C18 TMS end-capped $150 \mathrm{~mm} \times 30 \mathrm{~mm}$ HPLC column with water ( $0.05 \%$ formic acid): $\mathrm{MeOH}(0.05 \%$ formic acid) eluent system with the same UV-detection. The method utilized for semi-preparative purification was the following: 0-6 $\mathrm{min}$ : $14 \%$ iso and 6-9 $\mathrm{min}: 95 \%$ iso \& $9-12 \mathrm{~min}: 14 \%$ iso $\mathrm{MeOH}, 25 \mathrm{~mL} / \mathrm{min}$.

\subsection{Electrochemistry}

Cyclic voltammograms $(\mathrm{CV})$ were obtained in an argon atmosphere at room temperature $\left(\sim 20^{\circ} \mathrm{C}\right)$ using an AUTOLAB PGSTAT 100 potentiostat, or an AUTOLAB PGSTAT 204N potentiostat, equipped with a $3 \mathrm{~mm}$ glassy carbon (GC) working electrode, a Pt wire auxiliary electrode, and a saturated calomel electrode (SCE) as a reference. The solution was stirred between each measurement. The solution was allowed to equilibrate for $10 \mathrm{~s}$ at the start potential before starting the measurements. A step potential of $-0.9 \mathrm{mV}$ was used for 50,100 and $200 \mathrm{mV} / \mathrm{s}$ scan rates, and of $-2 \mathrm{mV}$ was used for 500 and 1000 $\mathrm{mV} / \mathrm{s}$ scan rates. For measurements in aqueous media the supporting electrolyte was $\mathrm{LiCl}(0.1 \mathrm{M})$, in the case of non-aqueous (DMF) solutions it was $\operatorname{TBAPF}_{6}(0.1 \mathrm{M})$.

General procedure for $\mathrm{CV}$ measurements in water: a solution of $\mathrm{LiCl}(0.1 \mathrm{M})$ was prepared and $\mathrm{pH}$ was set to $\sim 6.5$ by addition of $\mathrm{NaOH}(0.1 \mathrm{M})$ or $\mathrm{HCl}(0.1 \mathrm{M})$. This solution was added to the electrochemical cell, allowed to stir and purged with argon for $10 \mathrm{~min}$ prior to each measurement. The working electrode was polished with $0.05 \mu \mathrm{m}$ alumina on a polishing pad, washed with water and ethanol and dried with air. The three electrodes (GC working electrode, Pt wire auxiliary electrode, and SCE reference electrode) were inserted into the cell setup and a background scan was recorded with a scan rate of $100 \mathrm{mV} / \mathrm{s}$, and four sweeps. A lack of oxygen redox signal verified that oxygen had been removed below detectable levels. The Eu complex $(1 \mathrm{mM})$ was added in the solution, and the $\mathrm{pH}$ of the resulting solution was adjusted to $\sim 6.5$ (Table S1) by addition of $\mathrm{NaOH}(0.1 \mathrm{M})$ or $\mathrm{HCl}(0.1 \mathrm{M})$. The resulting solution was stirred and purged with argon for $10 \mathrm{~min}$. Scans were recorded at various scan rates (50 to $1000 \mathrm{mV} / \mathrm{s}$ ) with four sweeps for each measurement. The voltammograms obtained at various scan rates are shown in Figures S28-S34. The anodic and cathodic peak current intensities ( $I_{\mathrm{pa}}$ and $I_{\mathrm{pc}}$, respectively) were plotted vs. the square root of scan rate and fit to a linear regression to ensure that the electron transfer was heterogenous.

General procedure for CV measurements in DMF: a sample of $\mathrm{TBAPF}_{6}(194 \mathrm{mg})$ was dissolved in $5 \mathrm{~mL}$ of DMF $(0.1 \mathrm{M})$ and purged with argon for $10 \mathrm{~min}$. After detecting blank signal without oxygen redox events, the CVs were recorded as it is described in the procedure for aqueous media, with 1 $\mathrm{mM}$ concentration of Eu complex. At the end of each experiment a sample of Ferrocene $(\mathrm{Fc})$ was added at the tip of the spatula into the electrochemical cell to adjust potentials according to $\mathrm{Fc}^{0} / \mathrm{Fc}^{+}$ redox events vs SCE which was then shifted according to the difference vs NHE [45]. The cyclic voltammograms of increasing scan rates are displayed in Figures S35-S41.

\subsection{UV-Vis Absorption and Emission Spectroscopy}

All measurements were performed in PIPES-buffered HPLC water or $\mathrm{D}_{2} \mathrm{O}$ at $\mathrm{pH} 6.5$ or pD 6.5. [LnL] was nominally $10 \mu \mathrm{M}$; however, small quantities of Ln salts may diminish this. Glycerol was of $99.9+\%$ purity. Quartz cells with $1 \mathrm{~cm}$ optical pathlengths were used for the room temperature measurements. 
The absorbance spectra were measured by a Varian Cary 100 Bio UV-Visible spectrophotometer (VARIAN AUSTRALIA PTY LTD, Mulgrave, Victoria, Australia). The emission and excitation spectra, lifetimes, time-resolved spectra and quantum yields were recorded on a Horiba FluoroMax-4P (HORIBA Jobin Yvon, Edison, NJ, USA). All emissions were corrected by the wavelength sensitivity (correction function) of the spectrometer. All measurements were performed at room temperature unless stated otherwise.

Quantum yields were measured at room temperature, using quinine sulfate (QS) in $\mathrm{H}_{2} \mathrm{SO}_{4} 0.05$ $\mathrm{M}\left(\Phi_{\text {ref }}=0.59\right)$ as reference [39] in Equation (3). Quantum yields were calculated according to (3), with $\Phi_{\mathrm{S}}$ the quantum yield of the sample, $\Phi_{\text {ref }}$ the quantum yield of the reference, $I$ the integrated corrected emission intensity of the sample (s) and of the reference (ref), $f_{\mathrm{A}}$ the absorption factor of the sample (s) and of the reference (ref) at the excitation wavelength and $n$ the refractive indexes of the sample (s) and of the reference (ref). The concentration of the complexes was adjusted to obtain an absorbance around the maxima of the antennae matching that of the QS fluorescence standard. The excitation wavelength where the absorption factors of the samples and of the reference were the same was chosen (i.e., where the absorptions are identical). The corrected emission spectra of the sample and reference standard were then measured under the same conditions over the 330-800 nm (320-800 nm for carbostyril complexes) spectral range as well as blank samples containing only the solvent (i.e., PIPES-buffered aqueous solutions). The appropriate blanks were subtracted from their respective spectra, and the antenna fluorescence and $\operatorname{Ln}(\mathrm{III})$ luminescence were separated by fitting the section of the antenna emission overlapping the $\operatorname{Ln}(\mathrm{III})$ emission with an exponential decay or with a scaled emission spectrum from the corresponding Gd(III) complexes. The quantum yields were then calculated according to (3). The given relative error on the quantum yields $(\delta \Phi=\Delta \Phi / \Phi$, where $\Delta \Phi$ is the absolute error) take into account the accuracy of the spectrometer and of the integration procedure $\left[\delta\left(I_{\mathrm{S}} / I_{\text {ref }}\right)<2 \%\right]$, an error of $0.59 \pm 0.01$ on the quantum yield of the reference QS $\left[\delta\left(\Phi_{\text {ref }}\right)<\right.$ $2 \%]$, an error on the ratio of the absorption factors $\left[\delta\left(f_{\text {Aref }} / f_{\text {As }}\right)<5 \%\right.$, relative to the fixed absorption factor of the reference QS] and an error on the ratio of the squared refractive indexes $\left[\delta\left(n_{\mathrm{s}}{ }^{2} / n_{\mathrm{ref}}{ }^{2}\right)<\right.$ $1 \%,<0.25 \%$ around 1.333 for $\mathrm{H}_{2} \mathrm{O}$ [43] and 1.328 for $\mathrm{D}_{2} \mathrm{O}$ [44] on each individual refractive index], which sums to a total estimated relative error that should be $\delta \Phi_{\mathrm{s}}<10 \%$. A limit value of $10 \%$ is thus chosen.

$$
\Phi=\frac{I_{\mathrm{s}}}{I_{\text {ref }}} \times \frac{f_{\text {Aref }}}{f_{\text {As }}} \times \frac{\left(n_{\mathrm{s}}\right)^{2}}{\left(n_{\text {ref }}\right)^{2}} \times \Phi_{\text {ref }}
$$

Low temperature measurements were done in quartz capillaries $(0.2 \mathrm{~cm}$ optical pathlength) at $77 \mathrm{~K}$ by immersion in a liquid $\mathrm{N}_{2}$-filled quartz Dewar and with addition of glycerol (1 drop) to the solutions (9 drops) measured at room temperature.

Lifetimes in the millisecond range were recorded $0.05 \mathrm{~ms}$ after pulsed excitation at the excitation maxima ( $\lambda_{\mathrm{ex}}$ ) of either 315 (coumarin) or $327 \mathrm{~nm}$ (carbostyril) by measuring the decay of the lanthanide main emission peak (i.e., Sm $600 \mathrm{~nm}, \mathrm{Eu} 615 \mathrm{~nm}$ and Tb $545 \mathrm{~nm}$ ). The increments after the initial delay were adjusted between $0.2-20 \mu$ s depending on the lifetime in order to have a good sampling of the decay. The obtained data were fitted by single and double exponential decay models in OriginPro 9 (OriginLab Corporation, Northampton, MA, USA), and the most reliable value was chosen according to the adjusted $\mathrm{R}^{2}$ value and the shape of the residuals. A relative error of $10 \%$ is typically found among a series of measurements on the same sample.

Hydration numbers $(q)$ were obtained by measuring the lifetimes of the same quantity of complex in a PIPES buffered solution in $\mathrm{H}_{2} \mathrm{O}$ and in $\mathrm{D}_{2} \mathrm{O}$ and fitting the difference according to the model of Horrocks et al. [17], and Beeby et al. [18].

The NIR emission and excitation spectra were recorded on a Horiba Jobin Yvon Fluorolog3-22 instrument (HORIBA Jobin Yvon, Edison, NJ, USA), and were automatically corrected for wavelength dependent instrument sensitivity. 


\subsection{Synthetic Procedures and Characterization Data}

4. Known compound [22], new procedure. Coumarin $2(4,2.00 \mathrm{~g}, 9.21 \mathrm{mmol})$ and triethylamine (3.85 mL, $27.6 \mathrm{mmol}, 3.0$ equiv.) were dissolved in $28.2 \mathrm{~mL}$ DMF. The solution was cooled to $0{ }^{\circ} \mathrm{C}$ and chloroacetyl chloride $(3.19 \mathrm{~mL}, 36.8 \mathrm{mmol}, 4.0$ equiv.) was added dropwise while stirring. After $1 \mathrm{~h}$ at $0^{\circ} \mathrm{C}$ the solution was allowed to warm to r.t. The reaction proceeded for additional $2 \mathrm{~h}$, after which TLC analysis showed full conversion of the starting material. The solution was poured into water $(100 \mathrm{~mL})$, which resulted in the formation of a light brown suspension. The mixture was filtered, and the filter cake was washed with water, and the solid was dried in vacuo. The product was obtained as a light brown solid (2.54 g, 94\%). ${ }^{1} \mathrm{H}$ NMR (400 MHz, $\left.\mathrm{CDCl}_{3}\right) \delta$ ppm $7.55(\mathrm{~s}, 1 \mathrm{H}), 7.15$ (s, $\left.1 \mathrm{H}\right), 6.35$ $(\mathrm{s}, 1 \mathrm{H}), 4.19(\mathrm{dq}, J=14.5,7.0 \mathrm{~Hz}, 1 \mathrm{H}), 3.73(\mathrm{~d}, J=2.0 \mathrm{~Hz}, 2 \mathrm{H}), 3.26(\mathrm{dq}, J=14.0,7.0 \mathrm{~Hz}, 1 \mathrm{H}), 2.46$ $(\mathrm{s}, 3 \mathrm{H}), 2.33(\mathrm{~s}, 3 \mathrm{H}), 1.17(\mathrm{t}, J=7.0 \mathrm{~Hz}, 3 \mathrm{H}) ;{ }^{13} \mathrm{C} \mathrm{NMR}\left(101 \mathrm{MHz}, \mathrm{CDCl}_{3}\right) \delta(\mathrm{ppm})=165.7,160.2,152.2$, 151.4, 142.4, 132.2, 127.4, 120.6, 117.8, 116.3, 44.2, 41.7, 18.8, 17.6, 12.7; HR-ESI-MS obsd 316.07095, calcd $316.07109\left[(\mathrm{M}+\mathrm{Na})^{+}, \mathrm{M}=\mathrm{C}_{15} \mathrm{H}_{16} \mathrm{NO}_{3} \mathrm{Cl}\right]$.

L2c ${ }^{\text {Car }}$. A sample of 1 (188 mg, $\left.0.354 \mathrm{mmol}\right)$ was dissolved in DMF (5.1 mL) and DIPEA (308 $\mu \mathrm{L}$, $1.77 \mathrm{mmol}, 5.0$ equiv.) was added, followed by the addition of 2-bromoacetamide (161 $\mathrm{mg}, 1.17 \mathrm{mmol}$, 3.3 equiv.). The reaction mixture was let to stir overnight at r.t. When LCMS analysis showed full conversion to the product, DMF was removed by co-evaporation with toluene. The concentrated reaction mass was suspended in an equal mixture of THF: $\mathrm{Et}_{2} \mathrm{O}$ and an off-white precipitate was formed which was filtered and washed with diethyl ether $(209 \mathrm{mg}, 83 \%) .{ }^{1} \mathrm{H}$ NMR (400 MHz, DMSO-d6) $\delta$ ppm 1.34-1.51 (s, 9H), 2.10-2.48 and 2.53-4.55 (m, $32 \mathrm{H}(29 \mathrm{H}+3 \mathrm{H}$ solvent residuals), 4.67 (s, 2H), $6.52(\mathrm{~s}, 1 \mathrm{H}), 6.98-7.93(\mathrm{~m}, 9 \mathrm{H}), 11.84(\mathrm{~s}, 1 \mathrm{H}) ;{ }^{13} \mathrm{C}$ NMR (101 MHz, DMSO-d6) $\delta$ ppm 27.7, 48.6, 48.7, 50.1, 50.4, 51.5, 51.8, 52.1, 52.2, 53.6, 54.5, 54.7, 55.6, 56.3, 58.2, 70.2, 81.4, 81.6, 113.8, 117.0, 119.7, 120.9, $125.8,139.7,143.1,146.8,161.6,167.9,170.5,170.7,173.2 ; \mathrm{RP}-H P L C \mathrm{t}_{\mathrm{R}}=1.72,3.55 \mathrm{~min}, \operatorname{method}(\mathrm{a})$ from general procedures; ESI-MS obsd 702.57, calcd $702.39(\mathrm{M}+\mathrm{H})^{+}$; HR-ESI-MS obsd 370.6766, calcd $370.6782\left[(\mathrm{M}+\mathrm{K}+\mathrm{H})^{2+}, \mathrm{M}=\mathrm{C}_{33} \mathrm{H}_{51} \mathrm{~N}_{9} \mathrm{O}_{8}\right]$.

L2a ${ }^{\text {Car }}$. Method A. A sample of $\mathbf{L 2 C}^{\mathrm{Car}}(100 \mathrm{mg}, 0.142 \mathrm{mmol})$ was dissolved in a 1:1 mixture of $\mathrm{CH}_{2} \mathrm{Cl}_{2}$ and TFA (3.2 mL) and this solution was let to stir for overnight at r.t. After full conversion was observed the solvents were removed on the rotary evaporator (co-evaporation with toluene). The crude product was purified on semi-preparative HPLC using the method described in the general procedures to yield a brownish-white solid (78 $\mathrm{mg}, 85 \%)$. For characterization see Method B.

Method B. An excess of TFA $(0.76 \mathrm{~mL})$ was added into the vial containing L2cCar $(48 \mathrm{mg}$, $0.068 \mathrm{mmol})$. The sticky solid of $\mathbf{L} 2 \mathrm{c}^{\mathrm{Car}}$ was sonicated with TFA until complete dissolving. The resulting solution was transferred into a $5 \mathrm{~mL}$ round bottom flask and $\mathrm{CH}_{2} \mathrm{Cl}_{2}$ was added $(0.76 \mathrm{~mL})$. The formed beige suspension was stirred overnight at r.t. The next day $\mathrm{CH}_{2} \mathrm{Cl}_{2}$ was removed under low pressure and TFA was removed via evaporation in a mixture with toluene $(5 \mathrm{~mL})$. The remaining oily residue was dissolved in $0.5 \mathrm{~mL}$ of $\mathrm{MeOH}$ and a large excess of $\mathrm{Et}_{2} \mathrm{O}(5 \mathrm{~mL})$ was added. The precipitated product was filtered, dissolved in $\mathrm{MeOH}$ and the solution was dried under vacuum to afford beige solid (44 mg, 99\%). RP-HPLC $t_{R}=2.35 \mathrm{~min}$, method $(\mathrm{b})$ from general procedures; ${ }^{1} \mathrm{H} \mathrm{NMR}(400 \mathrm{MHz}$, $\left.\mathrm{D}_{2} \mathrm{O}\right) \delta$ ppm $2.70-4.75(\mathrm{~m}, 31 \mathrm{H}), 6.61(\mathrm{~s}, 1 \mathrm{H}), 7.33\left(\mathrm{dd}, J_{1}=8.5 \mathrm{~Hz}, J_{2}=2.0 \mathrm{~Hz}, 1 \mathrm{H}\right), 7.44(\mathrm{~d}, J=2.0 \mathrm{~Hz}$, $1 \mathrm{H}), 7.81(\mathrm{~d}, J=8.5 \mathrm{~Hz}, 1 \mathrm{H}) ;{ }^{13} \mathrm{C}$ NMR $\left(101 \mathrm{MHz}, \mathrm{D}_{2} \mathrm{O}\right) \delta \mathrm{ppm} 47.5-52.5,51.7,54.0,54.7,55.2,58.4$, 70.3, 115.2, 118.5, 118.7, 122.3, 126.3, 138.4, 142.4 (br), 148.8, 164.1, 165.0-176.0 (br), 172.8; ESI-MS obsd 646.51, calcd 646.33 $(\mathrm{M}+\mathrm{H})^{+}$; HR-ESI-MS obsd 646.3316, calcd 646.3313 [(M+ H) $\left.{ }^{+}, \mathrm{M}=\mathrm{C}_{29} \mathrm{H}_{43} \mathrm{~N}_{9} \mathrm{O}_{8}\right]$.

L2d ${ }^{\text {Cou }}$. Compound 6 (400 mg, $0.932 \mathrm{mmol}, 1.0$ equiv.), 2-bromoacetamide (514 mg, $3.73 \mathrm{mmol}$, 4.0 equiv.) and $\mathrm{K}_{2} \mathrm{CO}_{3}$ (773 mg, $5.59 \mathrm{mmol}, 6.0$ equiv.) were suspended in $\mathrm{MeCN}$ (9.3 mL) and stirred at $60{ }^{\circ} \mathrm{C}$ for 2.5 days. The solids were filtered off and the filtrate was concentrated under reduced pressure. The isolated solid was the target product together with an excess of potassium carbonate. Therefore, the solid mixture was dissolved in a minimal amount of $\mathrm{MeOH}$ and filtrated from $\mathrm{K}_{2} \mathrm{CO}_{3}$. After evaporation of the solvent the product was obtained as a light brown solid (442 $\mathrm{mg}, 79 \%) .{ }^{1} \mathrm{H}$ NMR (400 MHz, CD 3 OD) $\delta$ ppm 7.75 (s, 1H), 7.29 (s, 1H), $6.34(\mathrm{~s}, 1 \mathrm{H}), 4.09(\mathrm{dq}, J=14.0,7.1 \mathrm{~Hz}, 1 \mathrm{H})$, 3.95-3.64 (m, 3H), $3.27(\mathrm{~s}, 3 \mathrm{H}), 3.18-2.39(\mathrm{~m}, 20 \mathrm{H}), 2.32(\mathrm{~s}, 3 \mathrm{H}), 2.08-2.00(\mathrm{~m}, 2 \mathrm{H}), 1.12(\mathrm{t}, J=7.0 \mathrm{~Hz}, 3 \mathrm{H})$; 
${ }^{13} \mathrm{C}$ NMR (101 MHz, CD $\left.\mathrm{OD}\right) \delta$ ppm 176.1, 171.6, 162.5, 161.4, 158.9, 154.6, 153.3, 144.0, 129.0, 121.6, 118.6, 116.2, 64.6, 62.9, 62.4, 58.3, 44.8, 44.4, 17.5, 13.0; HR-ESI-MS obsd: 623.32682. calcd: 623.32760 [(M $+\mathrm{Na})^{+}, \mathrm{M}=\mathrm{C}_{29} \mathrm{H}_{44} \mathrm{~N}_{8} \mathrm{O}_{6}$.

\subsection{General Procedure for Ln (III) Complexation}

A sample of the appropriate ligand (1 equiv.) in the mixture with the corresponding anhydrous $\mathrm{LnCl}_{3}$ (1.05 equiv. for LnL1-2a,c Car and 1.50 equiv. for $\mathbf{L n L 1 - 2 d C o u}$ ) were dissolved in $\mathrm{H}_{2} \mathrm{O}: \mathrm{EtOH}$ equal mixture $(0.05 \mathrm{M})$. For the synthesis of $\mathbf{L n L 1 a ^ { C a r }}$ only water $(0.02 \mathrm{M})$ was used due to the low solubility of $\mathbf{L 1 a}{ }^{\text {Car }}$ in ethanol. The reaction mixtures were stirred at $55{ }^{\circ} \mathrm{C}$ for $24 \mathrm{~h}$. The completion of the complexation was observed via TLC analysis. The purification of LnL1aCar was done with column chromatography on neutral alumina (MeCN: $\mathrm{H}_{2} \mathrm{O}: \mathrm{NH}_{4} \mathrm{OH}$ (30\% aqueous solution), 80:20:3 drops $\rightarrow$ 50:50:9 drops) of the reaction mixtures yielding colorless complexes. The complexes of LnL2a Car were purified via semi-preparative HPLC using the method described in the general procedures.

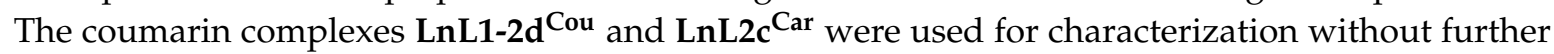
purification. The isolated compounds contain traces of initial lanthanide chlorides.

LaL1aCar $8 \mathrm{mg}(65 \%) .{ }^{1} \mathrm{H}$ NMR (400 MHz, $\mathrm{D}_{2} \mathrm{O}, 2$ isomers in 1:0.05 ratio, major isomer reported) $\delta$ ppm 1.96-4.61 ppm (m, 30.45H both isomers + 3H MeOH), $3.51(\mathrm{~s}, 3 \mathrm{H}), 4.84(\mathrm{~s}, 2 \mathrm{H}), 6.78(\mathrm{~s}, 1 \mathrm{H}), 7.39$ $\left(\mathrm{dd}, J_{1}=8.5 \mathrm{~Hz}, J_{2}=2.1 \mathrm{~Hz}, 1 \mathrm{H}\right), 7.54(\mathrm{~s}, 1 \mathrm{H}), 7.93(\mathrm{~d}, J=8.5 \mathrm{~Hz}, 1 \mathrm{H})$; ESI-MS obsd 783.12, calcd 783.15 $\left[(\mathrm{M})^{-}, \mathrm{M}=\mathrm{C}_{29} \mathrm{H}_{36} \mathrm{~N}_{6} \mathrm{O}_{11} \mathrm{La}\right] ; \lambda_{\mathrm{em}}=375 \mathrm{~nm}\left(\lambda_{\mathrm{ex}}=327 \mathrm{~nm}\right)$.

SmL1a ${ }^{\text {Car }} .9 \mathrm{mg}(72 \%)$. ESI-MS obsd 796.18, calcd 796.16 [(M) $\left.{ }^{-}, \mathrm{M}=\mathrm{C}_{29} \mathrm{H}_{36} \mathrm{~N}_{6} \mathrm{O}_{11} \mathrm{Sm}\right] ; \lambda_{\mathrm{em}}=376$, $563,568,593,601,608,644,651,656,704,713 \mathrm{~nm}\left(\lambda_{\mathrm{ex}}=327 \mathrm{~nm}\right)$.

YbL1aCar. $12 \mathrm{mg}(93 \%)$. ESI-MS obsd 818.17, calcd 818.18 [(M) $\left.{ }^{-}, \mathrm{M}=\mathrm{C}_{29} \mathrm{H}_{36} \mathrm{~N}_{6} \mathrm{O}_{11} \mathrm{Yb}\right]$; $\lambda_{\mathrm{em}}=375 \mathrm{~nm}\left(\lambda_{\mathrm{ex}}=327 \mathrm{~nm}\right)$.

LuL1aCar. $10 \mathrm{mg}(77 \%) .{ }^{1} \mathrm{H}$ NMR (400 MHz, $\mathrm{D}_{2} \mathrm{O}, 2$ isomers in 1:0.05 ratio, major isomer reported) $\delta$ ppm 2.25-4.15 ppm (m, 30.45H both isomers + 3H MeOH), $3.51(\mathrm{~s}, 3 \mathrm{H}), 4.85$ (s, 2H), $6.79(\mathrm{~s}, 1 \mathrm{H})$, $7.43(\mathrm{~d}, J=8.5 \mathrm{~Hz}, 1 \mathrm{H}), 7.57(\mathrm{~s}, 1 \mathrm{H}), 7.93(\mathrm{~d}, J=8.5 \mathrm{~Hz}, 1 \mathrm{H})$; ESI-MS obsd 819.19, calcd 819.19 [(M)- , $\left.\mathrm{M}=\mathrm{C}_{29} \mathrm{H}_{36} \mathrm{~N}_{6} \mathrm{O}_{11} \mathrm{Lu}\right] ; \lambda_{\mathrm{em}}=375 \mathrm{~nm}\left(\lambda_{\mathrm{ex}}=327 \mathrm{~nm}\right)$.

LaL2aCar. $31 \mathrm{mg}$ (quant.). ${ }^{1} \mathrm{H} \mathrm{NMR}\left(400 \mathrm{MHz}, \mathrm{D}_{2} \mathrm{O}, 2\right.$ isomers in 1:0.2 ratio, major isomer reported) $\delta$ ppm 1.97-3.23 and 3.28-4.75 ppm (m, 37.2H both isomers), $3.53(\mathrm{~s}, 3 \mathrm{H}), 6.77(\mathrm{~s}, 1 \mathrm{H}), 7.34(\mathrm{~d}, \mathrm{~J}=9.0 \mathrm{~Hz}$, $1 \mathrm{H}), 7.48(\mathrm{~s}, 1 \mathrm{H}), 7.91(\mathrm{~d}, J=8.0 \mathrm{~Hz}, 1 \mathrm{H})$; ESI-MS obsd 783.20, calcd 783.22 [(M) $\left.{ }^{+}, \mathrm{M}=\mathrm{C}_{29} \mathrm{H}_{42} \mathrm{~N}_{9} \mathrm{O}_{8} \mathrm{La}\right]$; $\lambda_{\mathrm{em}}=373 \mathrm{~nm}\left(\lambda_{\mathrm{ex}}=327 \mathrm{~nm}\right)$.

SmL2aCar. $23 \mathrm{mg}$ (quant.). ESI-MS obsd 796.24, calcd $796.24\left[(\mathrm{M})^{+}, \mathrm{M}=\mathrm{C}_{29} \mathrm{H}_{42} \mathrm{~N}_{9} \mathrm{O}_{8} \mathrm{Sm}\right]$; $\lambda_{\mathrm{em}}=374,562,567,593,600,607,643,650,654,704,712 \mathrm{~nm}\left(\lambda_{\mathrm{ex}}=327 \mathrm{~nm}\right)$.

EuL2aCar. $13 \mathrm{mg}(47 \%)$. RP-HPLC $t_{\mathrm{R}}=1.17 \mathrm{~min}$, method (a) from general procedures; ESI-MS obsd 398.72, calcd 398.62 (M) ${ }^{2+}$; HR-ESI-MS obsd 398.61797, calcd 398.61801 [(M $)^{2+}, \mathrm{M}=\mathrm{C}_{29} \mathrm{H}_{42} \mathrm{~N}_{9} \mathrm{O}_{8} \mathrm{Eu}$; $\lambda_{\mathrm{em}}=375,579,589,594,615,622,653,682,687,695,699,752,760 \mathrm{~nm}\left(\lambda_{\mathrm{ex}}=327 \mathrm{~nm}\right)$.

GdL2aCar. $6 \mathrm{mg}(44 \%)$. RP-HPLC $\mathrm{t}_{\mathrm{R}}=1.18 \mathrm{~min}$, method (a) from general procedures; ESI-MS obsd 401.13, calcd $401.12(\mathrm{M})^{2+}$; HR-ESI-MS obsd 401.11986, calcd $401.11965\left[(\mathrm{M})^{2+}, \mathrm{M}=\mathrm{C}_{29} \mathrm{H}_{42} \mathrm{~N}_{9} \mathrm{O}_{8} \mathrm{Gd}\right]$; $\lambda_{\mathrm{em}}=375 \mathrm{~nm}\left(\lambda_{\mathrm{ex}}=327 \mathrm{~nm}\right)$.

TbL2aCar. $9 \mathrm{mg}(65 \%)$. RP-HPLC $t_{\mathrm{R}}=1.18 \mathrm{~min}$, method (a) from general procedures; ESI-MS obsd 401.80, calcd 401.62 (M) ${ }^{2+}$; HR-ESI-MS obsd 401.61996, calcd $401.61994\left[(\mathrm{M})^{2+}, \mathrm{M}=\mathrm{C}_{29} \mathrm{H}_{42} \mathrm{~N}_{9} \mathrm{O}_{8} \mathrm{~Tb}\right]$; $\lambda_{\mathrm{em}}=374,487,542,545,581,587,620,640,650,667,680 \mathrm{~nm}\left(\lambda_{\mathrm{ex}}=327 \mathrm{~nm}\right)$.

YbL2a ${ }^{\text {Car }}$. $14 \mathrm{mg}(74 \%)$. ESI-MS obsd 817.19, calcd 817.25 [(M - H) $\left.{ }^{-}, \mathrm{M}=\mathrm{C}_{29} \mathrm{H}_{42} \mathrm{~N}_{9} \mathrm{O}_{8} \mathrm{Yb}\right]$; $\lambda_{\mathrm{em}}=374 \mathrm{~nm}\left(\lambda_{\mathrm{ex}}=327 \mathrm{~nm}\right)$.

LuL2aCar. $20 \mathrm{mg}$ (quant.). ${ }^{1} \mathrm{H}$ NMR (400 MHz, $\mathrm{D}_{2} \mathrm{O}, 2$ isomers in 1:0.2 ratio, major isomer reported) $\delta$ ppm 2.44-3.00 and 3.30-4.17 ppm (m, 37.2H both isomers), $3.51(\mathrm{~s}, 3 \mathrm{H}), 6.79$ (s, $1 \mathrm{H}), 7.38$ $(\mathrm{d}, J=8.0 \mathrm{~Hz}, 1 \mathrm{H}), 7.55(\mathrm{~s}, 1 \mathrm{H}), 7.93(\mathrm{~d}, J=8.5 \mathrm{~Hz}, 1 \mathrm{H})$; ESI-MS obsd 818.31, calcd $818.25\left[(\mathrm{M}-\mathrm{H})^{-}\right.$, $\left.\mathrm{M}=\mathrm{C}_{29} \mathrm{H}_{42} \mathrm{~N}_{9} \mathrm{O}_{8} \mathrm{Lu}\right] ; \lambda_{\mathrm{em}}=373 \mathrm{~nm}\left(\lambda_{\mathrm{ex}}=327 \mathrm{~nm}\right)$.

LaL2cCar. $4.7 \mathrm{mg}(92 \%)$. Partial characterization due to the complex being unstable. ${ }^{1} \mathrm{H}$ NMR $\left(400 \mathrm{MHz}, \mathrm{CD}_{3} \mathrm{OD}\right.$, mixture of LaL2aCar and $\mathbf{L a L 2 c}{ }^{\text {Car }}$ in 1:0.45 ratio, LaL2c Car peaks reported) $\delta$ ppm 
$1.30(\mathrm{~s}, 4.05 \mathrm{H}), 2.10-3.27$ and 3.57-4.35 ppm (m, 37.7H both species), $3.51(\mathrm{~s}, 4.35 \mathrm{H}), 4.76(\mathrm{~s}, 2.9 \mathrm{H}), 6.76$ $(\mathrm{s}, 0.45 \mathrm{H}), 7.41(\mathrm{~m}, 0.45 \mathrm{H}), 7.58(\mathrm{~s}, 0.45 \mathrm{H}), 7.89(\mathrm{~d}, J=8.0 \mathrm{~Hz}, 0.45 \mathrm{H}) ; \lambda_{\mathrm{em}}=374 \mathrm{~nm}\left(\lambda_{\mathrm{ex}}=327 \mathrm{~nm}\right)$.

SmL2c Car. $5.1 \mathrm{mg}(98 \%)$. Partial characterization due to the complex being unstable. $\lambda_{\mathrm{em}}=374$, $562,567,593,600,607,643,650,654,704,711 \mathrm{~nm}\left(\lambda_{\mathrm{ex}}=327 \mathrm{~nm}\right)$.

EuL2c Car $.6 .4 \mathrm{mg}$ (91\%). Partial characterization due to the complex being unstable. RP-HPLC $\mathrm{t}_{\mathrm{R}}=1.28 \mathrm{~min}$, method (a) from general procedures; ESI-MS obsd 449.62, calcd $449.14(\mathrm{M}+\mathrm{Na}-$ $\mathrm{H})^{2+}, \mathrm{M}=\mathrm{C}_{33} \mathrm{H}_{51} \mathrm{~N}_{9} \mathrm{O}_{8} \mathrm{Eu} ; \lambda_{\mathrm{em}}=374,579,589,594,615,623,653,682,687,695,699,752,761 \mathrm{~nm}$ $\left(\lambda_{\mathrm{ex}}=327 \mathrm{~nm}\right)$. HRMS shows only the hydrolyzed complex EuL2aCar. The LCMS obtained after overnight stirring shows 1:2 ratio of hydrolyzed: ${ }^{\mathrm{B}} \mathrm{Bu}$ species (Figure $\mathrm{S} 1$ ).

GdL2cCar. $4.9 \mathrm{mg}$ (70\%). Partial characterization due to the complex being unstable. RP-HPLC $\mathrm{t}_{\mathrm{R}}=1.27 \mathrm{~min}$, method (a) from general procedures; ESI-MS obsd 451.70, calcd $451.64(\mathrm{M}+\mathrm{Na}-\mathrm{H})^{2+}$, $\mathrm{M}=\mathrm{C}_{33} \mathrm{H}_{51} \mathrm{~N}_{9} \mathrm{O}_{8} \mathrm{Gd} ; \lambda_{\mathrm{em}}=374 \mathrm{~nm}\left(\lambda_{\mathrm{ex}}=327 \mathrm{~nm}\right)$. HRMS shows only the hydrolyzed complexes GdL2aCar. The LCMS obtained after overnight stirring shows 1:2 ratio of hydrolyzed: ${ }^{\mathrm{B}}$ Bu species (Figure S2).

TbL2cCar. $3.8 \mathrm{mg}$ (54\%). Partial characterization due to the complex being unstable. RP-HPLC $t_{R}=1.27$ min, method (a) from general procedures; ESI-MS obsd 452.57, calcd $452.14(\mathrm{M}+\mathrm{Na}-\mathrm{H})^{2+}$, $\mathrm{M}=\mathrm{C}_{33} \mathrm{H}_{51} \mathrm{~N}_{9} \mathrm{O}_{8} \mathrm{~Tb} ; \lambda_{\mathrm{em}}=373,487,545,545,582,587,620,640,650,667,680 \mathrm{~nm}\left(\lambda_{\mathrm{ex}}=327 \mathrm{~nm}\right)$. HRMS shows only the hydrolyzed complexes TbL2a ${ }^{\text {Car }}$. The LCMS obtained after overnight stirring shows 1:2 ratio of hydrolyzed:' ${ }^{\mathrm{B} u}$ species (Figure S3).

YbL2cCar. $5 \mathrm{mg}$ (98\%). Partial characterization due to the complex being unstable. $\lambda_{\mathrm{em}}=374 \mathrm{~nm}$ $\left(\lambda_{\mathrm{ex}}=327 \mathrm{~nm}\right)$.

LuL2cCar. $4.8 \mathrm{mg}$ (94\%). Partial characterization due to the complex being unstable. ${ }^{1} \mathrm{H}$ NMR $\left(400 \mathrm{MHz}, \mathrm{CD}_{3} \mathrm{OD}\right.$, mixture of LaL2a ${ }^{\text {Car }}$ and $\mathbf{L a L 2 c}{ }^{\mathrm{Car}}$ in 1:0.45 ratio, both species reported) $\delta$ ppm 1.29 (s, 2.25 H), 2.47-3.08 and 3.57-4.00 ppm (m, 32.5H both species), 3.51 (s, 3.75H), $4.76(\mathrm{~s}, 2.5 \mathrm{H}), 6.76-6.79$ $(\mathrm{s}, 1.25 \mathrm{H}), 7.37\left(\mathrm{dd}, J_{1}=8.5 \mathrm{~Hz}, J_{2}=2.0 \mathrm{~Hz}, 1.25 \mathrm{H}\right), 7.58(\mathrm{~s}, 1.25 \mathrm{H}), 7.91-7.98(\mathrm{~d}, J=8.0 \mathrm{~Hz}, 1.25 \mathrm{H})$; $\lambda_{\mathrm{em}}=375 \mathrm{~nm}\left(\lambda_{\mathrm{ex}}=327 \mathrm{~nm}\right)$.

LaL1d $^{\text {Cou }}$. $27 \mathrm{mg}$ (quant.); ${ }^{1} \mathrm{H}$ NMR (400 MHz, $\mathrm{D}_{2} \mathrm{O}, 2$ isomers in 1:0.33 ratio, major isomer reported) $\delta \mathrm{ppm} 1.16(\mathrm{t}, J=7.0 \mathrm{~Hz}, 3 \mathrm{H}), 2.36(\mathrm{~s}, 3 \mathrm{H}), 2.50(\mathrm{~s}, 3 \mathrm{H}) 2.82-3.90 \mathrm{ppm}(\mathrm{m}, 33.25 \mathrm{H}$ both isomers $+3 \mathrm{H} \mathrm{MeOH}), 4.19\left(\mathrm{dq}, J_{1}=15.0 \mathrm{~Hz}, J_{2}=7.5 \mathrm{~Hz}, 1 \mathrm{H}\right), 6.46(\mathrm{~s}, 1 \mathrm{H}), 7.48(\mathrm{~s}, 1 \mathrm{H}), 7.86$ (s, 1H); HR-ESI-MS m/z: obsd: 762.16330, calcd: $762.16252\left[(\mathrm{M}+\mathrm{Na})^{+}, \mathrm{M}=\mathrm{C}_{29} \mathrm{H}_{38} \mathrm{~N}_{5} \mathrm{O}\right.$ La $] ; \lambda_{\mathrm{em}}=387 \mathrm{~nm}\left(\lambda_{\mathrm{ex}}=315 \mathrm{~nm}\right)$.

SmL1d Cou. Known compound [20], new procedure. $16 \mathrm{mg}$ (quant.); HR-ESI-MS m/z: obsd: 775.17683, calcd: $775.17601\left[(\mathrm{M}+\mathrm{Na})^{+}, \mathrm{M}=\mathrm{C}_{29} \mathrm{H}_{38} \mathrm{~N}_{5} \mathrm{O}_{9} \mathrm{Sm}\right] ; \lambda_{\mathrm{em}}=383,563,568,592,601,608,650 \mathrm{~nm}$ $\left(\lambda_{\mathrm{ex}}=315 \mathrm{~nm}\right)$.

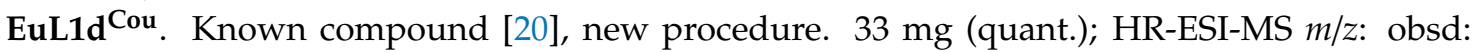
754.19657, calcd: $754.19573\left[(\mathrm{M}+\mathrm{H})^{+}, \mathrm{M}=\mathrm{C}_{29} \mathrm{H}_{38} \mathrm{~N}_{5} \mathrm{O}_{9} \mathrm{Eu}\right] ; \lambda_{\mathrm{em}}=387,579,588,594,614,623,653$, $682,688,694,700 \mathrm{~nm}\left(\lambda_{\mathrm{ex}}=315 \mathrm{~nm}\right)$.

GdL1d $^{\text {Cou }}$. Known compound [20], new procedure. $18 \mathrm{mg}$ (quant.); HR-ESI-MS m/z: obsd: 781.18182, calcd: $781.18098\left[(\mathrm{M}+\mathrm{Na})^{+}, \mathrm{M}=\mathrm{C}_{29} \mathrm{H}_{38} \mathrm{~N}_{5} \mathrm{O}_{9} \mathrm{Gd}\right] ; \lambda_{\mathrm{em}}=387 \mathrm{~nm}\left(\lambda_{\mathrm{ex}}=315 \mathrm{~nm}\right)$.

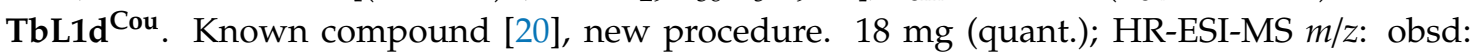
782.18214, calcd: $782.18152\left[(\mathrm{M}+\mathrm{Na})^{+}, \mathrm{M}=\mathrm{C}_{29} \mathrm{H}_{38} \mathrm{~N}_{5} \mathrm{O}_{9} \mathrm{~Tb}\right] ; \lambda_{\mathrm{em}}=389,487,542,545,583,587,620$, $651,668,682 \mathrm{~nm}\left(\lambda_{\mathrm{ex}}=315 \mathrm{~nm}\right)$.

YbL1d ${ }^{\text {Cou }} 33 \mathrm{mg}$ (quant.); HR-ESI-MS m/z: obsd: 797.19648, calcd: $797.19553\left[(\mathrm{M}+\mathrm{Na})^{+}\right.$, $\left.\mathrm{M}=\mathrm{C}_{29} \mathrm{H}_{38} \mathrm{~N}_{5} \mathrm{O}_{9} \mathrm{Yb}\right] ; \lambda_{\mathrm{em}}=388 \mathrm{~nm}\left(\lambda_{\mathrm{ex}}=315 \mathrm{~nm}\right)$.

LuL1d ${ }^{\text {Cou }}$. Known compound [20], new procedure. $26 \mathrm{mg}$ (quant.); ${ }^{1} \mathrm{H}$ NMR (400 MHz, D 20,2 isomers in 1:0.1 ratio, major isomer reported) $\delta \mathrm{ppm} 1.16(\mathrm{t}, J=7.0 \mathrm{~Hz}, 3 \mathrm{H}), 2.36(\mathrm{~s}, 3 \mathrm{H}), 2.50(\mathrm{~s}, 3 \mathrm{H})$ 2.57-3.72 ppm (m, 27.5H both isomers + 3H MeOH), $4.17(\mathrm{~m}, 1 \mathrm{H}), 6.46(\mathrm{~s}, 1 \mathrm{H}), 7.48(\mathrm{~s}, 1 \mathrm{H}), 7.87(\mathrm{~s}, 1 \mathrm{H})$; HR-ESI-MS m/z: obsd: 798.19742, calcd: $798.19694\left[(\mathrm{M}+\mathrm{Na})^{+}, \mathrm{M}=\mathrm{C}_{29} \mathrm{H}_{38} \mathrm{~N}_{5} \mathrm{O}_{9} \mathrm{Lu}\right] ; \lambda_{\mathrm{em}}=388 \mathrm{~nm}$ $\left(\lambda_{\mathrm{ex}}=315 \mathrm{~nm}\right)$.

LaL2d ${ }^{\text {Cou }}$. $24 \mathrm{mg}$ (quant.); ${ }^{1} \mathrm{H}$ NMR (400 MHz, $\mathrm{D}_{2} \mathrm{O}, 2$ isomers in 1:0.05 ratio, major isomer reported) $\delta$ ppm $1.16(\mathrm{~m}, 3 \mathrm{H}), 2.33(\mathrm{~s}, 3 \mathrm{H}), 2.50(\mathrm{~s}, 3 \mathrm{H}) 2.7-4.27 \mathrm{ppm}(\mathrm{m}, 27.3 \mathrm{H}$ both isomers $+3 \mathrm{H}$ 
$\mathrm{MeOH}), 6.48(\mathrm{~s}, 1 \mathrm{H}), 7.41(\mathrm{~s}, 1 \mathrm{H}), 7.87$ (s, 1H); HR-ESI-MS m/z: obsd: 369.11778, calcd: 369.11790 [(M $\left.\mathrm{H})^{2-}, \mathrm{M}=\mathrm{C}_{29} \mathrm{H}_{44} \mathrm{~N}_{8} \mathrm{O}_{6} \mathrm{La}\right] ; \lambda_{\mathrm{em}}=387 \mathrm{~nm}\left(\lambda_{\mathrm{ex}}=315 \mathrm{~nm}\right)$.

SmL2dCou. $16 \mathrm{mg}$ (quant.); HR-ESI-MS $m / z$ : obsd: 375.62442, calcd: $375.62464\left[(\mathrm{M}-\mathrm{H})^{2-}\right.$, $\left.\mathrm{M}=\mathrm{C}_{29} \mathrm{H}_{44} \mathrm{~N}_{8} \mathrm{O}_{6} \mathrm{Sm}\right] ; \lambda_{\mathrm{em}}=385,563,567,593,600,606,648 \mathrm{~nm}\left(\lambda_{\mathrm{ex}}=315 \mathrm{~nm}\right)$.

EuL2d ${ }^{\text {Cou }}$. $32 \mathrm{mg}$ (quant.); HR-ESI-MS $m / z$ : obsd: 375.12529 , calcd: $376.12547\left[(\mathrm{M}-\mathrm{H})^{2-}\right.$, $\left.\mathrm{M}=\mathrm{C}_{29} \mathrm{H}_{44} \mathrm{~N}_{8} \mathrm{O}_{6} \mathrm{Eu}\right] ; \lambda_{\mathrm{em}}=387,579,593,615,623,653,682,688,700 \mathrm{~nm}\left(\lambda_{\mathrm{ex}}=315 \mathrm{~nm}\right)$.

GdL2d $^{\text {Cou } . ~} 17 \mathrm{mg}$ (quant.); HR-ESI-MS m/z: obsd: 378.62684, calcd: $378.62711\left[(\mathrm{M}-\mathrm{H})^{2-}\right.$, $\left.\mathrm{M}=\mathrm{C}_{29} \mathrm{H}_{44} \mathrm{~N}_{8} \mathrm{O}_{6} \mathrm{Gd}\right] ; \lambda_{\mathrm{em}}=386 \mathrm{~nm}\left(\lambda_{\mathrm{ex}}=315 \mathrm{~nm}\right)$.

TbL2d ${ }^{\text {Cou }} .17 \mathrm{mg}$ (quant.); HR-ESI-MS $m / z$ : obsd: 379.12710 , calcd: $379.12740\left[(\mathrm{M}-\mathrm{H})^{2-}\right.$, $\left.\mathrm{M}=\mathrm{C}_{29} \mathrm{H}_{44} \mathrm{~N}_{8} \mathrm{O}_{6} \mathrm{~Tb}\right] ; \lambda_{\mathrm{em}}=387,487,545,582,587,620,650,667,680 \mathrm{~nm}\left(\lambda_{\mathrm{ex}}=315 \mathrm{~nm}\right)$.

YbL2d ${ }^{\text {Cou }}$. $32 \mathrm{mg}$ (quant.); HR-ESI-MS $m / z$ : obsd: 386.63411, calcd: $386.63439\left[(\mathrm{M}-\mathrm{H})^{2-}\right.$, $\left.\mathrm{M}=\mathrm{C}_{29} \mathrm{H}_{44} \mathrm{~N}_{8} \mathrm{O}_{6} \mathrm{Yb}\right] ; \lambda_{\mathrm{em}}=387 \mathrm{~nm}\left(\lambda_{\mathrm{ex}}=315 \mathrm{~nm}\right)$.

LuL2d ${ }^{\mathrm{Cou}}$. $25 \mathrm{mg}$ (quant.); ${ }^{1} \mathrm{H}$ NMR (400 MHz, $\mathrm{D}_{2} \mathrm{O}, 2$ isomers in 1:0.15 ratio, major isomer reported) $\delta \mathrm{ppm} 1.17(\mathrm{t}, J=7.0 \mathrm{~Hz}, 3 \mathrm{H}), 2.36(\mathrm{~s}, 3 \mathrm{H}), 2.51(\mathrm{~s}, 3 \mathrm{H}) 2.57-3.06$ and $3.20-4.25 \mathrm{ppm}(\mathrm{m}, 29.9 \mathrm{H}$ both isomers + 9H 3MeOH), $6.48(\mathrm{~s}, 1 \mathrm{H}), 7.43(\mathrm{~d}, J=23.0 \mathrm{~Hz}, 1 \mathrm{H}), 7.88(\mathrm{~d}, J=10.0 \mathrm{~Hz}, 1 \mathrm{H})$; HR-ESI-MS m/z: obsd: 387.13483 , calcd: $387.13511\left[(\mathrm{M}-\mathrm{H})^{2-}, \mathrm{M}=\mathrm{C}_{29} \mathrm{H}_{44} \mathrm{~N}_{8} \mathrm{O}_{6} \mathrm{Lu}\right] ; \lambda_{\mathrm{em}}=388 \mathrm{~nm}\left(\lambda_{\mathrm{ex}}=315 \mathrm{~nm}\right)$.

\section{Conclusions}

Octadentate ligands carrying 4-methoxymethylcarbostyril or coumarin 2 sensitizing antennae mounted on a DO3A ligand binding site were prepared and characterized. Paramagnetic ${ }^{1} \mathrm{H}$ NMR spectroscopy indicated that the coumarin-carrying ligands existed as a mixture of SAP rotamers, possibly due to the steric clash between the antenna 6-Me group and the linker carbonyl. Only one species was seen for the carbostyrils with $\mathrm{H}$ in the 6-position. The $\mathrm{Eu}(\mathrm{III}) / \mathrm{Eu}(\mathrm{II})$ reduction potentials were found to be quite unaffected by the nature of the amide linker (secondary vs tertiary) between the antenna and the metal binding site. The Eu(III) oxidation state was nevertheless stabilized by a negatively charged methylcarboxylate substituent on the tertiary amide linker.

$\mathrm{Ln}(\mathrm{III})(\mathrm{Ln}=\mathrm{Eu}, \mathrm{Tb}, \mathrm{Sm})$ emission was detected from both coumarin and carbostyril-sensitized complexes. The coumarin antenna was unexpectedly ineffective in sensitizing $\operatorname{Ln}(\mathrm{III})$ emission. In the case of the Eu(III) complexes, the low overall quantum yield appears to be caused by low sensitization efficiency. While a large part of the excitation energy was eliminated due to PeT in the triamide carbostyril complex, this quenching pathway did not seem prominent in the coumarin 2-sensitized +3-charged species. This was indicated by the lack of improvement in Eu(III) sensitization efficiency upon the stabilization of the +3 oxidation state via fluoride binding. These results underscore the importance of understanding the structures of emitters in solution and show that superficially similar complexes can be subject to different quenching processes.

Supplementary Materials: The following are available online, characterization data for new compounds $\left({ }^{1} \mathrm{H}\right.$ and ${ }^{13} \mathrm{C}$ NMR spectra) and for new complexes (LC-MS analysis for $\mathbf{L n L 2 C} \mathrm{Car},{ }^{1} \mathrm{H}$ NMR spectra), additional photophysical and electrochemical characterization of $\mathbf{L n L},{ }^{1} \mathrm{H}$ and ${ }^{19} \mathrm{~F}$ NMR spectra and photophysical characterization of LnL-F.

Author Contributions: Conceptualization, S.R.K. and K.E.B.; methodology, S.R.K.; formal analysis, S.R.K., F.S. and K.E.B.; data curation, S.R.K., E.M., F.S., D.K., E.D.; writing—original draft preparation, S.R.K., F.S. and K.E.B.; writing - review and editing, all authors; visualization, S.R.K., E.M., D.K.; supervision, project administration, and funding acquisition, K.E.B. All authors have read and agreed to the published version of the manuscript.

Funding: This research was funded by the Swedish Research Council, grant number 2017-04077, the Carl Tryggers Stiftelse för veteskaplig forskning, and the Knut och Alice Wallenbergs Foundation, Dnr: 2018.0066.

Conflicts of Interest: The authors declare no conflict of interest. The funders had no role in the design of the study; in the collection, analyses, or interpretation of data; in the writing of the manuscript, or in the decision to publish the results. 


\section{References}

1. Bünzli, J.-C.G. Lanthanide Luminescence for Biomedical Analyses and Imaging. Chem. Rev. 2010, 110, 2729-2755. [CrossRef] [PubMed]

2. Eliseeva, S.V.; Bünzli, J.-C.G. Lanthanide luminescence for functional materials and bio-sciences. Chem. Soc. Rev. 2009, 39, 189-227. [CrossRef] [PubMed]

3. Andres, J.; Hersch, R.D.; Moser, J.-E.; Chauvin, A.-S. A New Anti-Counterfeiting Feature Relying on Invisible Luminescent Full Color Images Printed with Lanthanide-Based Inks. Adv. Funct. Mater. 2014, 24, 5029-5036. [CrossRef]

4. Guillou, O.; Daiguebonne, C.; Calvez, G.; Bernot, K. A Long Journey in Lanthanide Chemistry: From Fundamental Crystallogenesis Studies to Commercial Anticounterfeiting Taggants. Acc. Chem. Res. 2016, 49, 844-856. [CrossRef]

5. Kaczmarek, A.M.; Liu, Y.-Y.; Wang, C.; Laforce, B.; Vincze, L.; Van Der Voort, P.; Van Hecke, K.; Van Deun, R. Lanthanide "Chameleon" Multistage Anti-Counterfeit Materials. Adv. Funct. Mater. 2017, 27, 1700258. [CrossRef]

6. de Bettencourt-Dias, A. Introduction to Lanthanide Ion Luminescence. In Luminescence of Lanthanide Ions in Coordination Compounds and Nanomaterials; John Wiley \& Sons Ltd.: Hoboken, NJ, USA, 2014; pp. 1-48.

7. Bünzli, J.-C.G.; Eliseeva, S.V. Basics of Lanthanide Photophysics. In Lanthanide Luminescence: Photophysical, Analytical and Biological Aspects; Hänninen, P., Härmä, H., Eds.; Springer: Berlin/Heidelberg, Germany, 2011; pp. 1-45.

8. Kovacs, D.; Kiraev, S.R.; Phipps, D.; Orthaber, A.; Borbas, K.E. Eu(III) and Tb(III) Complexes of Octaand Nonadentate Macrocyclic Ligands Carrying Azide, Alkyne, and Ester Reactive Groups. Inorg. Chem. 2020, 59, 106-117. [CrossRef]

9. Kenwright, A.M.; Kuprov, I.; De Luca, E.; Parker, D.; Pandya, S.U.; Senanayake, P.K.; Smith, D.G. 19F NMR based $\mathrm{pH}$ probes: Lanthanide(iii) complexes with $\mathrm{pH}$-sensitive chemical shifts. Chem. Commun. 2008, 22, 2514-2516. [CrossRef]

10. Pershagen, E.; Borbas, K.E. Designing reactivity-based responsive lanthanide probes for multicolor detection in biological systems. Coord. Chem. Rev. 2014, 273-274, 30-46. [CrossRef]

11. Pershagen, E.; Nordholm, J.; Borbas, K.E. Luminescent Lanthanide Complexes with Analyte-Triggered Antenna Formation. J. Am. Chem. Soc. 2012, 134, 9832-9835. [CrossRef]

12. Pershagen, E.; Borbas, K.E. Multiplex Detection of Enzymatic Activity with Responsive Lanthanide-Based Luminescent Probes. Angew. Chem. Int. Ed. 2015, 54, 1787-1790. [CrossRef]

13. Parker, D. Luminescent lanthanide sensors for pH, pO2 and selected anions. Coord. Chem. Rev. 2000, 205, 109-130. [CrossRef]

14. Law, G.-L.; Pal, R.; Palsson, L.O.; Parker, D.; Wong, K.-L. Responsive and reactive terbium complexes with an azaxanthone sensitiser and one naphthyl group: Applications in ratiometric oxygen sensing in vitro and in regioselective cell killing. Chem. Commun. 2009, 47, 7321-7323. [CrossRef] [PubMed]

15. Bunzli, J.-C.G. On the design of highly luminescent lanthanide complexes. Coord. Chem. Rev. 2015, 293-294, 19-47. [CrossRef]

16. Cotton, S. Coordination Chemistry of the Lanthanides. In Lanthanide and Actinide Chemistry; Wiley: Hoboken, NJ, USA, 2006; pp. 35-60.

17. Supkowski, R.M.; Horrocks, W.D., Jr. On the determination of the number of water molecules, q, coordinated to europium(III) ions in solution from luminescence decay lifetimes. Inorg. Chim. Acta 2002, 340, 44-48. [CrossRef]

18. Beeby, A.; Clarkson, I.M.; Dickins, R.S.; Faulkner, S.; Parker, D.; Royle, L.; de Sousa, A.S.; Williams, J.A.G.; Woods, M. Non-radiative deactivation of the excited states of europium, terbium and ytterbium complexes by proximate energy-matched $\mathrm{OH}, \mathrm{NH}$ and $\mathrm{CH}$ oscillators: An improved luminescence method for establishing solution hydration states. J. Chem. Soc. Perkin Trans. 1999, 2, 493-504. [CrossRef]

19. Kovacs, D.; Phipps, D.; Orthaber, A.; Borbas, K.E. Highly luminescent lanthanide complexes sensitized by tertiary amide-linked carbostyril antennae. Dalton Trans. 2018, 47, 10702-10714. [CrossRef] [PubMed]

20. Kovacs, D.; Lu, X.; Mészáros, L.S.; Ott, M.; Andres, J.; Borbas, K.E. Photophysics of Coumarin and Carbostyril-Sensitized Luminescent Lanthanide Complexes: Implications for Complex Design in Multiplex Detection. J. Am. Chem. Soc. 2017, 139, 5756-5767. [CrossRef] 
21. Vithanarachchi, S.M.; Kovacs, D.; Borbas, K.E. Synthesis and photophysical characterization of luminescent lanthanide complexes of nucleotide-functionalized cyclen- and dipicolinate-based ligands. Inorg. Chim. Acta 2017, 460, 148-158. [CrossRef]

22. Borbas, K.E.; Bruce, J.I. Synthesis of asymmetrically substituted cyclen-based ligands for the controlled sensitization of lanthanides. Org. Biomol. Chem. 2007, 5, 2274-2282. [CrossRef]

23. Nielsen, L.G.; Sørensen, T.J. Including and Declaring Structural Fluctuations in the Study of Lanthanide(III) Coordination Chemistry in Solution. Inorg. Chem. 2020, 59, 94-105. [CrossRef]

24. Mani, T.; Tircsó, G.; Zhao, P.; Sherry, A.D.; Woods, M. Effect of the Regiochemistry of Butyl Amide Substituents on the Solution-State Structures of Lanthanide(III) DOTA-Tetraamide Complexes. Inorg. Chem. 2009, 48, 10338-10345. [CrossRef]

25. Blackburn, O.A.; Routledge, J.D.; Jennings, L.B.; Rees, N.H.; Kenwright, A.M.; Beer, P.D.; Faulkner, S. Substituent effects on fluoride binding by lanthanide complexes of DOTA-tetraamides. Dalton Trans. 2016, 45, 3070-3077. [CrossRef] [PubMed]

26. Hoeft, S.; Roth, K. Struktur und Dynamik von Lanthanoid-Tetraazacyclododecantetraacetat-(DOTA-)Komplexen in Lösung. Chem. Ber. 1993, 126, 869-873. [CrossRef]

27. Jacques, V;; Desreux, J.F. Quantitative Two-Dimensional EXSY Spectroscopy and Dynamic Behavior of a Paramagnetic Lanthanide Macrocyclic Chelate: YbDOTA(DOTA = 1,4,7,10-Tetraazacyclododecane- $\mathrm{N}, \mathrm{N}^{\prime}, \mathrm{N}^{\prime \prime}, \mathrm{N}^{\prime \prime \prime}$-tetraacetic Acid). Inorg. Chem. 1994, 33, 4048-4053. [CrossRef]

28. Cotton, S. The Lanthanides-Principles and Energetics. In Lanthanide and Actinide Chemistry; John Wiley \& Sons, Ltd.: Hoboken, NJ, USA, 2006; pp. 9-22.

29. Parker, D.; Williams, J.A.G. Modest effectiveness of carbostyril 124 as a sensitizing chromophore in europium and terbium amide complexes based on 1,4,7,10-tetraazacyclododecane. J. Chem. Soc. Perkin Trans. 1996, 2, 1581-1586. [CrossRef]

30. Kovacs, D.; Borbas, K.E. The role of photoinduced electron transfer in the quenching of sensitized Europium emission. Coord. Chem. Rev. 2018, 364, 1-9. [CrossRef]

31. Gamage, N.-D.H.; Mei, Y.; Garcia, J.; Allen, M.J. Oxidatively Stable, Aqueous Europium(II) Complexes through Steric and Electronic Manipulation of Cryptand Coordination Chemistry. Angew. Chem. Int. Ed. 2010, 49, 8923-8925. [CrossRef]

32. Burai, L.; Tóth, É.; Moreau, G.; Sour, A.; Scopelliti, R.; Merbach, A.E. Novel Macrocyclic EuII Complexes: Fast Water Exchange Related to an Extreme M-Owater Distance. Chem. A Eur. J. 2003, 9, 1394-1404. [CrossRef]

33. Burai, L.; Scopelliti, R.; Tóth, É. EuII-cryptate with optimal water exchange and electronic relaxation: A synthon for potential pO2 responsive macromolecular MRI contrast agents. Chem. Commun. 2002, 20, 2366-2367. [CrossRef]

34. Tóth, É.; Burai, L.; Merbach, A.E. Similarities and differences between the isoelectronic GdIII and EuII complexes with regard to MRI contrast agent applications. Coord. Chem. Rev. 2001, 216-217, 363-382.

35. Burai, L.; Tóth, É.; Seibig, S.; Scopelliti, R.; Merbach, A.E. Solution and Solid-State Characterization of EuII Chelates: A Possible Route Towards Redox Responsive MRI Contrast Agents. Chem. A Eur. J. 2000, 6, 3761-3770. [CrossRef]

36. Kovacs, D.; Mathieu, E.; Kiraev, S.R.; Wells, J.A.L.; Demeyere, E.; Sipos, A.; Borbas, K.E. Coordination Environment-Controlled Photoinduced Electron Transfer Quenching in Luminescent Europium Complexes. J. Am. Chem. Soc. 2020, 142, 13190-13200. [CrossRef] [PubMed]

37. Carnall, W.T.; Crosswhite, H.; Crosswhite, H.M. Energy Level Structure and Transition Probabilities in the Spectra of the Trivalent Lanthanides in $\mathrm{LaF}_{3}$; ANL-78-XX-95; TRN: 79-005910 United States 10.2172/6417825 TRN: 79-005910 Dep. NTIS, PC A09/MF A01. ANL English; Argonne National Lab. (ANL): Argonne, IL, USA, $1978 ; 195 p$.

38. Latva, M.; Takalo, H.; Mukkala, V.-M.; Matachescu, C.; Rodriguez-Ubis, J.C.; Kankare, J. Correlation between the lowest triplet state energy level of the ligand and lanthanide(III) luminescence quantum yield. J. Lumin. 1997, 75, 149-169. [CrossRef]

39. Suzuki, K.; Kobayashi, A.; Kaneko, S.; Takehira, K.; Yoshihara, T.; Ishida, H.; Shiina, Y.; Oishi, S.; Tobita, S. Reevaluation of absolute luminescence quantum yields of standard solutions using a spectrometer with an integrating sphere and a back-thinned CCD detector. Phys. Chem. Chem. Phys. 2009, 11, 9850-9860. [CrossRef] [PubMed] 
40. Horrocks, W.D.; Sudnick, D.R. Lanthanide ion luminescence probes of the structure of biological macromolecules. Acc. Chem. Res. 1981, 14, 384-392. [CrossRef]

41. Binnemans, K. Interpretation of europium(III) spectra. Coord. Chem. Rev. 2015, 295, 1-45. [CrossRef]

42. Werts, M.H.V.; Jukes, R.T.F.; Verhoeven, J.W. The emission spectrum and the radiative lifetime of Eu3+ in luminescent lanthanide complexes. Phys. Chem. Chem. Phys. 2002, 4, 1542-1548. [CrossRef]

43. Harvey, A.H.; Gallagher, J.S.; Sengers, J.M.H.L. Revised Formulation for the Refractive Index of Water and Steam as a Function of Wavelength, Temperature and Density. J. Phys. Chem. Ref. Data 1998, 27, 761-774. [CrossRef]

44. Odhner, H.; Jacobs, D.T. Refractive Index of Liquid D2O for Visible Wavelengths. J. Chem. Eng. Data 2012, 57, 166-168. [CrossRef]

45. Connelly, N.G.; Geiger, W.E. Chemical Redox Agents for Organometallic Chemistry. Chem. Rev. 1996, 96, 877-910. [CrossRef]

Sample Availability: Samples of the compounds LnL2d ${ }^{\mathrm{Cou}}(\mathrm{Ln}=\mathrm{La}, \mathrm{Lu}-15 \mathrm{mg}, \mathrm{Ln}=\mathrm{Sm}, \mathrm{Gd}, \mathrm{Tb}-10 \mathrm{mg}$, $\mathrm{Ln}=\mathrm{Eu}, \mathrm{Yb}-20 \mathrm{mg}$ ) are available from the authors.

Publisher's Note: MDPI stays neutral with regard to jurisdictional claims in published maps and institutional affiliations.

(C) 2020 by the authors. Licensee MDPI, Basel, Switzerland. This article is an open access article distributed under the terms and conditions of the Creative Commons Attribution (CC BY) license (http://creativecommons.org/licenses/by/4.0/). 